\title{
BIBLIOGRAPHY
}

\section{Bibliography of urban history 2020}

\author{
Andrew McTominey
}

The present bibliography is a continuation of and a complement to those published in the Urban History Yearbook 1974-91 and Urban History from 1992. The arrangement and format closely follows that of previous years. The list of abbreviations identifies only those periodicals from which articles cited this year have been taken, though many other journals are also checked.

\section{General}

Research methods, aids and materials

Maps and plans

Archives - descriptions and examples

Urban history, definitions and aims

Historiography

Theory of urbanization

Empirical studies of urbanization

History, growth and fortunes of individual towns

Literary portrayals and personal reminiscences

\section{Population}

Research methods, aids and materials

General features of urban population

Natality and mortality

Disease

Medicine

Migration to, from and between towns

Family and household structure

\section{Physical structure}

Research methods, aids and materials Physical and structural characteristics of towns

Physical and structural characteristics of area

Architecture

Housing

Heritage and the historic environment

\section{Social structure}

Research methods, aids and materials

Social organization, clubs and societies

Class structure

Social life

Social life, customs and traditions

(c) The Author(s), 2020. Published by Cambridge University Press. 
Religion

Recreation

Social problems and deviance

Social reforms and improvement

Minority groups

Family life

Gender

Sexualities

\section{Economic activity}

Urban economic activity

Industry

External trade

Food supply

Finance, banking and industry

Consumption

Earnings

Standard of living

Working conditions

Labour organization

\section{Communications}

Inter-urban communications

Intra-urban communications

\section{Politics and administration}

Aspects of urban administration

Political activism

\section{Shaping the urban environment}

Town planning (and environmental control)

Utopian planning and experiments

Urban renewal

\section{Urban culture}

Research methods, aids and materials

Urban culture and entertainment

Forms of entertainment

Exchange of information

Education

Emotions and the senses

\section{Attitudes towards cities}

Attitudes towards cities

Views of the city in literature, graphics and drama 


\section{Journals abbreviations used}

\begin{tabular}{|c|c|}
\hline$A$ & Antiquity \\
\hline$A \& R$ & Archives \& Records \\
\hline$A A A G$ & Annals of the American Association of Geographers \\
\hline$A D H$ & Annals de démographie historique \\
\hline$A J$ & Archaeological Journal \\
\hline$A N H$ & Archives of Natural History \\
\hline Arc & Archives \\
\hline $\operatorname{ArchH}$ & Architectural History \\
\hline AtlSt & Atlantic Studies \\
\hline$B \& L$ & Buildings and Landscapes \\
\hline BatW & Britain and the World \\
\hline BHM & Bulletin of the History of Medicine \\
\hline BJHS & British Journal for the History of Science \\
\hline$B O E C$ & Book of the Old Edinburgh Club \\
\hline BookH & Book History \\
\hline$B Q$ & Baptist Quarterly \\
\hline $\mathrm{BuH}$ & Business History \\
\hline $\mathrm{CBH}$ & Contemporary British History \\
\hline $\mathrm{CBMH}$ & Canadian Bulletin of Medical History \\
\hline $\mathrm{CEH}$ & Central European History \\
\hline $\mathrm{ChH}$ & Church History \\
\hline ChP & Childhood in the Past \\
\hline CitC & City and Community \\
\hline ContC & Continuity and Change \\
\hline $\mathrm{CSSH}$ & Comparative Studies in Society and History \\
\hline CulSH & Cultural and Social History \\
\hline$D C$ & Dutch Crossing \\
\hline$E A m S$ & Early American Studies \\
\hline $\mathrm{EcHR}$ & Economic History Review \\
\hline ECS & Eighteenth Century Studies \\
\hline$E I$ & Éire-Ireland \\
\hline Emus & Early Music \\
\hline$E M W$ & Early Modern Women \\
\hline $\mathrm{EnH}$ & Environmental History \\
\hline$E n v H$ & Environment and History \\
\hline$E P B$ & Environment and Planning $B$ \\
\hline$E P C$ & Environment and Planning $C$ \\
\hline$E P D$ & Environment and Planning $D$ \\
\hline$E R C$ & Explorations in Renaissance Culture \\
\hline ES & Enterprise and Society \\
\hline EurRH & European Review of History \\
\hline $\mathrm{FCH}$ & Family and Community History \\
\hline $\mathrm{FH}$ & French History \\
\hline FHS & French Historical Studies \\
\hline$G \& H$ & Gender and History \\
\hline $\mathrm{GeH}$ & German History \\
\hline$G F H$ & Global Food History \\
\hline$H$ & History \\
\hline$H A$ & History Australia \\
\hline$H C$ & History Compass \\
\hline$H E$ & History of Education \\
\hline$H F$ & History of the Family \\
\hline Hire & History Ireland \\
\hline
\end{tabular}


HJ

$H M$

$H R$

$H R / R H$

$H R C$

HT

HU

$H W J$

$I$ \& $M$

$I A R$

IESH

IESHR

IHS

IJHA

IJHerS

IJHS

IJMH

IJRLH

IJURR

ILWCH

IM

IRSH

ISR

$J A$

$J A E H$

$J A f r H$

$J A S c$

JBAA

$J B S$

$\mathrm{JCCH}$

$\mathrm{JeH}$

JEMH

JFH

$J G R$

JHC

JHels

JHG

JHMAS

JHS

$\mathrm{JICH}$

$J M H$

$J M o d H$

$J P H$

JPopC

JSEAS

JSocH

JTH

JUH

$J W H$

JWomH

$L \& H R$

$\mathrm{LabH}$

LandH

LHR

LJ
Historical Journal

Historical Methods

Historical Research

Historical Reflections/Réflexions historiques

History of Retailing and Consumption

History Today

Histoire urbaine

History Workshop Journal

Immigrants \& Minorities

Industrial Archaeology Review

Irish Economic and Social History

Indian Economic and Social History Review

Irish Historical Studies

International Journal of Historical Archaeology

International Journal of Heritage Studies

International Journal of the History of Sport

International Journal of Maritime History

International Journal of Regional and Local History

International Journal of Urban and Regional Research

International Labor and Working-Class History

Imago Mundi

International Review of Social History

Irish Studies Review

Journal of Architecture

Journal of American Ethnic History

Journal of African History

Journal of Archaeological Science

Journal of the British Archaeological Association

Journal of British Studies

Journal of Colonialism and Colonial History

Jewish History

Journal of Early Modern History

Journal of Family History

Journal of Genocide Research

Journal of the History of Collections

Journal of Hellenic Studies

Journal of Historical Geography

Journal of the History of Medicine and Allied Services

Journal of Historical Sociology

Journal of Imperial and Commonwealth History

Journal of Medieval History

Journal of Modern History

Journal of Planning History

Journal of Popular Culture

Journal of South East Asian Studies

Journal of Social History

Journal of Tourism History

Journal of Urban History

Journal of World History

Journal of Women's History

Law and History Review

Labor History

Landscape History

Labour History Review

London Journal 


\begin{tabular}{|c|c|}
\hline $\mathrm{LocH}$ & Local Historian \\
\hline LPS & Local Population Studies \\
\hline MAsS & Modern Asian Studies \\
\hline$M E S$ & Middle Eastern Studies \\
\hline$M H$ & Medical History \\
\hline MidH & Midland History \\
\hline$M M$ & Mariner's Mirror \\
\hline $\mathrm{MuHJ}$ & Museum History Journal \\
\hline NCTF & Nineteenth Century Theatre and Film \\
\hline $\mathrm{NH}$ & Northern History \\
\hline NTQ & New Theatre Quarterly \\
\hline$P \& P$ & Past \& Present \\
\hline PaedH & Paedagogica Historica \\
\hline ParlH & Parliamentary History \\
\hline $\mathrm{PH}$ & Pennsylvania History \\
\hline$P l P$ & Planning Perspectives \\
\hline$P M A$ & Post-Medieval Archaeology \\
\hline$P Q$ & Print Quarterly \\
\hline$R \& C$ & Race and Class \\
\hline$R H$ & Rural History \\
\hline RHR & Radical History Review \\
\hline$R S$ & Renaissance Studies \\
\hline $\operatorname{SaA}$ & Slavery and Abolition \\
\hline SAs & South Asia \\
\hline $\mathrm{SCH}$ & Studies in Church History \\
\hline SH & Social History \\
\hline Sha & Shakespeare \\
\hline SHGD & Studies in the History of Gardens and Design \\
\hline SHMed & Social History of Medicine \\
\hline SJH & Scandinavian Journal of History \\
\hline$S L H$ & Scottish Labour History \\
\hline Spec & Speculum \\
\hline $\mathrm{SpiH}$ & Sport in History \\
\hline TCBH & Twentieth Century British History \\
\hline$T h J$ & Theatre Journal \\
\hline$U H$ & Urban History \\
\hline US & Urban Studies \\
\hline$V A$ & Vernacular Architecture \\
\hline$V C B$ & Visual Culture in Britain \\
\hline$V L \& C$ & Victorian Literature and Culture \\
\hline$V P R$ & Victorian Periodicals Review \\
\hline$W H$ & Water History \\
\hline$W H R$ & Welsh History Review \\
\hline WomHR & Women's History Review \\
\hline$Y A J$ & Yorkshire Archaeological Journal \\
\hline
\end{tabular}

\section{General}

\section{Research methods, aids and materials}

1 JONES P, Urban governance and its disorders: corruption in the cities. IJRLH 142 (2019) 55-61.

2 LEGG S, Subjects of truth: resisting governmentality in Foucoult's 1980s. EPD 371 (2019) 27-45.

3 PAISLEY F \& SCULLY P, Writing transnational history. London: Bloomsbury Academic 2019. pp 252. 


\section{Maps and plans}

4 FERDINAND S, Mapping beyond measure: art, cartography, and the space of global modernity. Lincoln, NE: University of Nebraska Press 2019. pp 318.

5 VANHAELEN A, Mapping angels in early modern Amsterdam. JEMH 23 2-3 (2019) 227-56.

6 WITHERS C W J, On trial - social relations of map production in mid-nineteenth-century Britain. IM 712 (2019) 173-95.

\section{Archives - descriptions and examples}

7 MCKEE E, The origins and development of the Public Record Office of Northern Ireland, 1922-1948. $A \& R 402$ (2019) 164-78.

8 O'LEARY D K, New Netherlands, archival deficiency, and contesting New York history in the Antebellum US. DC 433 (2019) 252-69.

9 REYNOLDS E A, Hidden pavements: the records of the Westminster Paving Commission. Arc 542 (2019) 47-58.

10 TICKELL S, 'The most dangerous enemies to shopkeepers': eighteenth-century shoplifting in the archive. Arc 542 (2019) 37-46.

\section{Urban history, definitions and aims}

11 AMEEL L, FINCH J, LAINE S \& DENNIS R, Urban history and the materialities of/in literature. In AMEEL L, FINCH J, LAINE S \& DENNIS R eds, The materiality of literary narratives in urban history. Abingdon: Routledge 2019. 1-16.

12 DICKSON D, What happened to modern Irish urban history? UH 461 (2019) 10-20.

13 FU C \& CAO W, An urban history of China. London: Palgrave Macmillan 2019. pp xxxi + 317.

14 HANNA E \& BUTLER R, Irish urban history: an agenda. UH 461 (2019) 2-9.

15 OTTER C, Beyond cities, beyond nature: building a European urban stratum. In SOENS T, SCHOTT D, TOYKA-SEID M \& DE MUNCK B eds, Urbanizing nature: actors and agency (dis)connecting cities and nature since 1500. Abingdon: Routledge 2019. 316-32.

16 PANZRAM S, Urban history on the Iberian Peninsula - current perspectives. In PANZRAM S ed, The power of cities: the Iberian Peninsula from late antiquity to the early modern period. Leiden: Brill 2019. $1-35$.

17 ROSENTHAL A, Sin cities: from history to sociology to urban history, an interdisciplinary journey. JUH 454 (2019) 656-70.

\section{Historiography}

18 BUYLAERT F, VERHOEVEN G, VERMOESEN R \& VERLAAN T, Review of periodical articles. UH 462 (2019) 331-55.

19 DE CAMARGO M A P, Historiography of school architecture in the state of São Paulo: the nineteenth century amidst history and architecture. PaedH 551 (2019) 70-87.

20 FU C \& CAO W, Introduction to the urban history of China. London: Palgrave Macmillan 2019. pp $\mathrm{xxxiii}+385$.

21 HARRIS R, A portrait of North American urban historians. JUH 456 (2019) 1237-45.

22 HEIN C, What's in a cover image? How to depict planning history. PlP 344 (2019) 737-47.

23 MARTÍNEZ G, Urban historiography in Latin America: a comparative perspective of research routes. UH 464 (2019) 747-66.

24 PANZRAM S, The power of cities - rewriting the history of the Iberian Peninsula. In PANZRAM S ed, The power of cities: the Iberian Peninsula from late antiquity to the early modern period. Leiden: Brill 2019. 362-72.

25 PUTTEVILS J, The urban history of the medieval Low Countries: research trends and new perspectives (2011-2018). UH 463 (2019) 542-54.

\section{Theory of urbanization}

26 CARRA G \& BARTHELEMY M, A fundamental diagram of urbanization. EPB 464 (2019) 690-706. 
DIBBLE J, PRELORENDJOS A, ROMICE O, ZANELLA M, STRANO E, PAGEL M \& PORTA S, On the origin of spaces: morphometric foundations of urban form evolution. EPB 464 (2019) 707-30.

28 VELLINGA M, The end of cities: Erwin Anton Gutkind and the inevitability of decentralization and dispersal. PlP 344 (2019) 621-41.

\section{Empirical studies of urbanization}

29 GARCIA M T, Cultural keys to the evolution of Spanish urbanism. JUH 451 (2019) 44-66.

\section{History, growth and fortunes of individual towns}

This section is arranged alphabetically by the name of the town

30 HANANIA M D, From colony to capital: reconsidering the socio-economic and political history of Amman, 1878-1928. MES 551 (2019) 1-21.

31 LAVAUD S, Bordeaux from its vineyards to its hinterland: a regional capital in the late Middle Ages. In FAVERO G, SERRUYS M-W \& SUGIURA M eds, The urban logistic network: cities, transport and distribution in Europe from the Middle Ages to modern times. London: Palgrave Macmillan 2019. 53-73.

32 MURPHY N, The Tudor occupation of Boulogne: conquest, colonisation and imperial monarchy, 15441550. Cambridge: Cambridge University Press 2019. pp xviii +296.

33 DE BOODT M, 'How one shall govern a city': the polyphony of urban political thought in the fourteenth-century duchy of Brabant. UH 464 (2019) 578-96.

34 MALPASS P, The making of Victorian Bristol. Woodbridge: Boydell \& Brewer 2019. pp xli +269.

35 SEN R, Birth of a colonial city: Calcutta. Abingdon: Routledge 2019. pp 262.

36 TORAL-NIEHOFF I \& MUÑOZ A L, Ornament of the world: urban change in early Islamic Qurțba. In PANZRAM S ed, The power of cities: the Iberian Peninsula from late antiquity to the early modern period. Leiden: Brill 2019. 107-60.

37 DONNELLY T, Coventry: a growing city. In BEGLEY J, DONNELLY T, JARVIS D \& SISSONS P eds, Revival of a city: Coventry in a globalising world. London: Palgrave Macmillan 2019. 11-39.

38 KATZ K, Hebron between Jordan and Egypt: an uncertain transition resulting from the 1948 Palestine War. UH 461 (2019) 132-48.

39 RIPOLL G, The transformation of the city of Hispania between the 4 th and the 6 th centuries. In PANZRAM S ed, The power of cities: the Iberian Peninsula from late antiquity to the early modern period. Leiden: Brill 2019. 39-83.

40 SARSHAR S, Power and identity: the case of Islamabad. JUH 452 (2019) 247-64.

41 INAL O, The making of an eastern Mediterranean gateway city: Izmir in the nineteenth century. JUH 455 (2019) 891-907.

42 KING J A, Ruins of Jamestown. B \& L 261 (2019) 11-31.

43 SIERRA L M, Colonial specters: the extramuro, history, memory, and urbanization in La Paz, Bolivia, 1900-1947. JUH 456 (2019) 1131-52.

44 ENGEL E A, Introduction: locating an American capital in the early modern world. In ENGEL E A ed, A companion to early modern Lima. Leiden: Brill 2019. 1-23.

45 JACK M, Lisbon, city of the seas: a history. London: I.B. Tauris 2019. pp 256.

46 PERALTA E \& DOMINGOS N, Lisbon: reading the (post-)colonial city from the nineteenth to the twenty-first century. UH 462 (2019) 246-65.

47 STAMMWITZ U, The beginnings and early development of Lübeck's central settlement. In JAHNKE $\mathrm{C}$ ed, A companion to medieval Lübeck. Leiden: Brill 2019. 18-35.

48 VON SEGGERN H, The 'Niederstadtbuch': a source for the history of private life of Lübeckers around 1500. In JAHNKE C ed, A companion to medieval Lübeck. Leiden: Brill 2019. 352-71

49 JARRATT D, The development and decline of Morecambe in the nineteenth and twentieth centuries: a resort caught in the tide. JTH 113 (2019) 263-83.

50 GURWITZ A, Atlantic metropolis: an economic history of New York City. London: Palgrave Macmillan 2019. pp $\mathrm{xxx}+737$.

51 CARRÉ G, Osaka, 1868-1945: the crucible of modern Japan. HU 552 (2019) 5-11.

52 HARRISON C, Paris in modern times: from the old regime to the present day. London: Bloomsbury Academic 2019. pp 360. 
53 HEATH A, In union there is strength: Philadelphia in the age of urban consolidation. Philadelphia: University of Pennsylvania Press 2019. pp 296.

54 HOU S, Nature's tonic: beer, ecology, and urbanization in a Chinese city, 1900-50. EnH 242 (2019) 282-306.

55 HENNING J, MCCORMICK M, ENCISO L O, RASSMANN K \& EYUB E F, Reccopolis revealed: the first geomagnetic mapping of the early medieval Visigothic royal town. A 93369 (2019) 735-51.

56 FOSI I, The plural city: urban spaces and foreign communities. In JONES P M, WISCH B \& DITCHFIELD S eds, A companion to early modern Rome, 1492-1692. Leiden: Brill 2019. 169-83.

57 ASCHERI M \& FRANCO B, A history of Siena: from its origins to the present day. Abingdon: Routledge 2019. pp 160.

58 BARR M D, Singapore: a modern history. London: Bloomsbury Academic 2019. pp 296.

59 GIACOMIN V, Singapore, global city ante litteram in early twentieth century Southeast Asia. In WEBSTER A \& WHITE N J eds, Singapore - two hundred years of the Lion City. Abingdon: Routledge 2019. 62-81.

60 HUFF G \& HUFF G, Singapore during the World War II Japanese occupation. In WEBSTER A \& WHITE N J eds, Singapore - two hundred years of the Lion City. Abingdon: Routledge 2019. 82-98.

61 WEBSTER A \& WHITE N J, Introduction: situating Singapore's success. In WEBSTER A \& WHITE N J eds, Singapore - two hundred years of the Lion City. Abingdon: Routledge 2019. 1-10.

62 ROLANDSEN O H \& KINDERSLEY N, The nasty war: organised violence during the Anya-Nya insurgency in South Sudan, 1963-72. JAfrH 601 (2019) 87-107.

\section{Literary portrayals and personal reminiscences}

63 BADER M, Life and love in Nazi Prague: letters from an occupied city. London: Bloomsbury Academic 2019. pp 304.

64 CRESSWELL T, Maxwell Street: writing and thinking place. Chicago: University of Chicago Press 2019. pp 264.

65 GIAMBONA G, The rhythm of the city: Roddy Doyle on Dublin, the past, identity and the healing power of the city. ISR 272 (2019) 253-64.

66 HULL C, Our Graham Greene in Havana. HT 698 (2019) 18-20.

67 NEAL S, Mediators, migrants and memories of colonial Singapore: the life and legacy of Seah Eu Chin. In WEBSTER A \& WHITE N J eds, Singapore - two hundred years of the Lion City. Abingdon: Routledge 2019. 140-55.

68 TYSZKA J, Grotowski in New York City, 1993: expectations, hopes, and stereotypes. NTQ 352 (2019) 150-68.

\section{Population}

\section{Research methods, aids and materials}

69 PINEDA A, CÁCERES I, SALADIÉ P, HUGUET R, MORALES J I, ROSAS A \& VALLVERDÚ J, Tumbling effects on bone surface modifications (BSM): an experimental application on archaeological deposits from the Barranc de la Boella site (Tarragona, Spain). JASc 1021 (2019) 35-47.

\section{General features of urban population}

70 PERNER M L, Segregated behind the walls: residential patterns in pre-industrial Copenhagen. SH 444 (2019) 412-39.

71 SHUMAKER T H, Estimating population sizes and demographic trends in Ipswich c. 1570-1620: re-evaluations and new approaches. LPS 1031 (2019) 7-25.

\section{Natality and mortality}

72 CHAPMAN J, The contribution of infrastructure investment to Britain's urban mortality decline, 1861-1900. EcHR 721 (2019) 233-59. 
73 DE LOOPER M W, BOOTH H \& BAFFOUR B, Sanitary improvement and mortality decline in Sydney, New South Wales, 1857-1906: drinking water and dunnies as determinants. HF 242 (2019) 227-48.

74 EVANS C M \& EVANS A E, Plague - a disease of children and servants? A study of the parish records of St Peter upon Cornhill, London from 1580 to 1605. ContC 342 (2019) 183-208.

75 FLORIS J \& STAUB K, Water, sanitation and mortality in Swiss towns in the context of urban renewal in the late nineteenth century. HF 242 (2019) 249-76.

76 HARRIS B \& HELGERTZ J, Urban sanitation and the decline of mortality. HF 242 (2019) 207-26.

77 HARRIS B \& HINDE A, Sanitary investment and the decline of urban mortality in England and Wales, 1817-1914. HF 242 (2019) 339-376.

78 HELGERTZ J \& ÖNNERFORS M, Public water and sewerage investments and the urban mortality decline in Sweden 1875-1930. HF 242 (2019) 307-38.

79 HINDE A \& HARRIS B, Mortality decline by cause in urban and rural England and Wales, 18511910. HF 242 (2019) 377-403.

80 MAZZARELLI D, GIBELLI D, MATTIA M, BERTOGLIO B, SGUAZZA E, FEDELI A M \& CATTANEO C, First signs of torture in Italy: a probable case of execution by the wheel on a skeleton from 13th century Milano. JASc 1091 (2019) 1-5.

81 MURPHY E, DONNELLY C \& MCKEAN D, In a city of mills and canals: mortality among pre-teen and teenage Irish workers in mid-nineteenth-century industrial Lowell, Massachusetts. ChP 122 (2019) 117-28.

82 O'CONNELL T C, BALLANTYNE R M, HAMILTON-DYER S, MARGARITIS E, OXFORD S, PANTANO W, MILLETT M \& KEAY S J, Living and dying at the Portus Romae. A 93369 (2019) 719-34.

83 PELTOLA J \& SAARITSA S, Later, smaller, better? Water infrastructure and infant mortality in Finnish cities and towns, 1870-1938. HF 242 (2019) 277-306.

\section{Disease}

84 COOMANS J, The king of dirt: public health and sanitation in late medieval Ghent. UH 461 (2019) 82-105.

85 DAVENPORT R J, SATCHELL M \& SHAW-TAYLOR L M W, Cholera as a 'sanitary test' of British cities, 1831-1866. HF 242 (2019) 404-38.

86 EVENDEN M, Debating water purity and expertise: the chlorination controversy in Vancouver during the Second World War. JHG 651 (2019) 85-95.

87 FERNANDES S, An uneasy pleasure: representing the dangers of skin-to-skin contact in eighteenthcentury London. MH 634 (2019) 494-511.

88 GREEN D, BROWN D, MCILVENNA K, \& SHELTON N, 'The postman wears out fast': retiring sick in London's Victorian Post Office. LJ 443 (2019) 180-205.

89 HARDING V, Reading plague in seventeenth-century London. SHMed 312 (2019) 267-86.

90 HENDERSON J, Florence under siege: surviving plague in an early modern city. New Haven: Yale University Press 2019. pp 376.

91 KISSANE A, The Black Death and the borough court: the changing pattern of social and judicial representation in late medieval Lincoln. In GODDARD $\mathrm{R} \&$ PHIPPS $\mathrm{T}$ eds, Town courts and urban society in late medieval England, 1250-1500. Woodbridge: Boydell \& Brewer 2019. 136-55.

92 LOH K S \& HSU L Y, Tuberculosis - the Singapore experience, 1867-2018: disease, society and the state. Abingdon: Routledge 2019. pp 170.

93 RAWSON G, The accommodation, experiences and concerns of the mentally unwell poor in mid-nineteenth-century Leeds. YAJ 911 (2019) 144-61.

94 REILLY B J, Northern European patterns of visiting Rome, 1400-1850. JTH 112 (2019) 101-23.

95 SCHÖHL S \& HESS V, War imprisonment and clinical narratives of psychiatric illness, psychiatric hospital Charité, Berlin, 1948-1956. JHMAS 742 (2019) 145-66.

96 SUMMERS M, Madness in the city of magnificent intentions: a history of race and mental illness in the nation's capital. Oxford: Oxford University Press 2019. pp 408. 
97 TULLETT W, Re-odorization, disease, and emotion in mid-nineteenth-century England. HJ 623 (2019) 765-88.

\section{Medicine}

98 BROWN M, Surgery, identity and embodied emotion: John Bell, James Gregory and the Edinburgh 'Medical War'. H 104359 (2019) 19-41.

99 COUZENS K-A, 'Upon my word, I do not see the use of medical evidence here': persuasion, authority and medical expertise in the Edinburgh High Court of Justiciary. H 104359 (2019) 42-62.

100 DI GIAMMATTEO L \& MENDELSOHN J A, Reporting for action: forms of writing between medicine and polity in Milan, 1580-1650. In MENDELSOHN J A, KINZELBACH A \& SCHILLING R eds, Civic medicine: physician, polity, and pen in early modern Europe. Abingdon: Routledge 2019. $132-59$.

101 DORNER Z, From Chelsea to Savannah: medicines and mercantilism in the Atlantic world. JBS 581 (2019) 28-57.

102 DROSS F, De officiis: doctors' oaths and appointments in early modern Nuremberg. In MENDELSOHN J A, KINZELBACH A \& SCHILLING R eds, Civic medicine: physician, polity, and pen in early modern Europe. Abingdon: Routledge 2019. 106-30.

103 HUANG J, The historical face of narcotic revisited: a Chinese city's fifty-year quest for hygienic modernity, 1900-49. MH 631 (2019) 82-94.

104 HUYNH G, University of Alberta hospital acute and convalescent polio care and the reintegration of polio patients into Albertan communities, 1953-80. CBMH 361 (2019) 112-30.

105 KEMPLEY E, Julian Trevelyan, Walter Maclay and Eric Guttmann: drawing the boundary between psychiatry and art at the Maudsley Hospital. BJHS 522 (2019) 617-43.

106 KINZELBACH A, Negotiating on paper: councilors, medical officers, and patients in an early modern city. In MENDELSOHN J A, KINZELBACH A \& SCHILLING R eds, Civic medicine: physician, polity, and pen in early modern Europe. Abingdon: Routledge 2019. 160-80.

107 MAJERUS B, A chemical revolution as seen from below: the 'discovery' of neuroleptics in 1950s Paris. SHMed 312 (2019) 395-413.

108 MENDELSOHN J A, Public practice: the European longue durée of knowing for health and polity. In MENDELSOHN J A, KINZELBACH A \& SCHILLING R eds, Civic medicine: physician, polity, and pen in early modern Europe. Abingdon: Routledge 2019. 1-58.

109 MINUZZI S, 'Quick to say quack'. Medicinal secrets from the household to the Apothecary's shop in eighteenth-century Venice. SHMed 311 (2019) 1-33.

110 PERREAULT I \& THIFAULT M-C, Behind asylum walls: studying the dialectic between psychiatrists and patients at Montreal's Saint-Jean-de-Dieu Hospital during the first half of the twentieth century. SHMed 312 (2019) 377-94.

111 POMATA G, A sense of place: town physicians and the resources of locality in early modern medicine. In MENDELSOHN J A, KINZELBACH A \& SCHILLING R eds, Civic medicine: physician, polity, and pen in early modern Europe. Abingdon: Routledge 2019. 211-36.

112 PUGLIANO V, Accountability, autobiography, and belonging: the working journal of a sixteenthcentury diplomatic physician between Venice and Damascus. In MENDELSOHN J A, KINZELBACH A \& SCHILLING R eds, Civic medicine. Abingdon: Routledge 2019. 182-210.

113 RITCH A, Sickness in the workhouse: poor law medical care in provincial England, 1834-1914. Woodbridge: Boydell \& Brewer 2019. pp xiv +299.

114 SCHILLING R, Physical city: a royal physician's Warsaw. In MENDELSOHN J A, KINZELBACH A \& SCHILLING R eds, Civic medicine: physician, polity, and pen in early modern Europe. Abingdon: Routledge 2019. 237-56.

115 SCHLEGELMILCH S, Promoting a good physician: letters of application to German civic authorities, 1500-1700. In MENDELSOHN J A, KINZELBACH A \& SCHILLING R eds, Civic medicine: physician, polity, and pen in early modern Europe. Abingdon: Routledge 2018. 83-105.

116 STOLBERG M, The many uses of writing: a humanist physician in sixteenth-century Prague. In MENDELSOHN J A, KINZELBACH A \& SCHILLING R eds, Civic medicine: physician, polity, and pen in early modern Europe. Abingdon: Routledge 2019. 60-82. 
117 WANG J, Mad dogs and other New Yorkers: rabies, medicine, and society in an American metropolis, 1840-1920. Baltimore, MD: Johns Hopkins University Press 2019. pp 344.

\section{Migration to, from and between towns}

118 BROCK A L \& VAN LOTTUM J, Rural maritime labour migration to Copenhagen and Stockholm (1700-1800). ContC 342 (2019) 231-52.

119 CRANKSHAW O \& BOREL-SALADIN J, Causes of urbanisation and counter-urbanisation in Zambia: natural population increase or migration? US 5610 (2019) 2005-20.

120 DATTA A B, Genealogy of a partition city: war, migration and urban space in Delhi. SAs 421 (2019) 152-69.

121 DEAN T, Police forces in late medieval Italy: Bologna, 1340-1480. SH 442 (2019) 151-72.

122 GOOCH D J, 'A town built on migration?' Calculating the human capital value of migration to Reading, 1851-1871. LPS 1031 (2019) 26-54.

123 JODOIN N, Les consuls Picciotto et Poche, intermédiaires des intérêts belges à Alep (1855-1914). In WINTER S \& ADE M eds, Aleppo and its hinterland in the Ottoman period/Alep et sa province à l'époque ottomane. Leiden: Brill 2019. 229-60.

124 ROOSEN J \& CURTIS D R, The 'light touch' of the Black Death in the Southern Netherlands: an urban trick? EcHR 721 (2019) 32-56.

125 SANTINI D, The exiles: actors, artists and writers who fled the Nazis for London. London: Bloomsbury Academic 2019. pp 288.

126 SCHÜRER K \& DAY J, Migration to London and the development of the north-south divide, 18511911. SH 441 (2019) 26-56.

127 SISSONS P, Population, migration and commuting patterns in a changing city. In BEGLEY J, DONNELLY T, JARVIS D \& SISSONS P eds, Revival of a city: Coventry in a globalising world. London: Palgrave Macmillan 2019. 143-64.

128 STAN N, Singapore, Chinese migration and the making of the British empire, 1819-67. Woodbridge: Boydell \& Brewer 2019. pp xviii +184.

129 ZYSIAK A, People will enter the downtown - the postwar ruralisation of the proletarian city of Łódź (1945-55). RH 301 (2019) 71-86.

\section{Family and household structure}

130 DAVENPORT R J, Infant-feeding practices and infant survival by familial wealth in London, 17521812. HF 241 (2019) 174-206.

131 PIMM-SMITH R, District schools and the erosion of parental rights under the Poor Law: a case study from London (1889-1899). ContC 343 (2019) 401-23.

132 VERMEESCH G, Facing illegitimate motherhood in eighteenth-century Antwerp: how changing contexts influenced the experiences of single mothers. ContC 341 (2019) 117-37.

\section{Physical structure}

\section{Research methods, aids and materials}

133 HERMAN A-M, How (repeat) museum displays are always experimental: (re-)making MUM and the city-laboratory. IJHerS 258 (2019) 796-807.

134 SHELTON T \& POORTHUIS A, The nature of neighborhoods: using big data to rethink the geographies of Atlanta's neighborhood planning unit system. AAAG 1095 (2019) 1341-61.

\section{Physical and structural characteristics of towns}

135 ARCE J, The late antique city in Spania - Toledo and Recópolis. In PANZRAM S ed, The power of cities: the Iberian Peninsula from late antiquity to the early modern period. Leiden: Brill 2019. 84-104.

136 CHEVANCE J-B, EVANS D, HOFER N, SAKHOEUN S \& CHHEAN R, Mahendraparvata: an early Angkor-period capital defined through airborne laser scanning at Phnom Kulen. A 93371 (2019) 1303-21. 
137 FEINTUCK A, Constructing cartographic authority: the conceptualization and mapping of urban spaces in Edinburgh, c. 1880 - c. 1920. UH 463 (2019) 464-92.

138 HANSON J W, ORTMAN S G, BETTENCOURT L M A \& MAZUR L C, Urban form, infrastructure and spatial organisation in the Roman Empire. A 93369 (2019) 702-18.

139 HARROWER M J, DUMITRU I A, PERLINGIERI C, NATHAN S, ZERUE K, LAMONT J L, BAUSI A, SWERIDA J L, BONGERS J L, WOLDEKIROS H S, POOLMAN L A, POHL C M, BRANDT S A \& PETERSON E A, Beta Samati: discovery and excavation of an Aksumite town. A 93372 (2019) 1534-52.

140 HORN A, The history of urban growth management in South Africa: tracking the origin and current status of urban edge policies in three metropolitan municipalities. PlP 346 (2019) 959-77.

141 LÓPEZ A I, Characteristics of Castilian cities in the 16th and 17th centuries. In PANZRAM S ed, The power of cities: the Iberian Peninsula from late antiquity to the early modern period. Leiden: Brill 2019. 289-320.

142 NELSON A, Architectural tradition and modernity as crypto-colonial ways of seeing: a comparison of Kathmandu's 1934 and 2015 post-quake reconstructions. HC 178 (2019) 1-11.

143 ROGERSDOTTER E, City tales in dialogue: Vijayanagara through travelogues and archaeology. In AMEEL L, FINCH J, LAINE S \& DENNIS R eds, The materiality of literary narratives in urban history. Abingdon: Routledge 2019. 234-55.

144 TAHARI B E-H \& KASSAB T, Relief morphology and urban hydrography as historical sources: Algiers in the beginning of the Ottoman period. IJHA 231 (2019) 57-80.

145 WEBER K \& DOS SANTOS ARNOLD T, Ports to 'new worlds': Lisbon, Seville, Cádiz (15th-18th centuries). In PANZRAM S ed, The power of cities: the Iberian Peninsula from late antiquity to the early modern period. Leiden: Brill 2019. 321-61.

146 ZIEGLER V, From wic to burh: a new approach to the question of the development of early medieval London. AJ 1762 (2019) 336-68.

\section{Physical and structural characteristics of area}

147 BOODROOKAS A \& KESHAVARZIAN A, The forever frontier of urbanism: historicizing Persian Gulf cities. IJURR 431 (2019) 14-29.

\section{Architecture}

148 ADAMS A, Designing Penfield: inside the Montreal neurological institute. BHM 932 (2019) 207-40.

149 ALDOVINI L, The woodcut-covered ceiling of the monastery of the Romite Ambrosiane in Varese. PQ 363 (2019) 251-62.

150 ANDREW P R, 'Contributions at St Petersburg': patriotic support for public monuments in Edinburgh in the early nineteenth century. BOEC 151 (2019) 119-32.

151 BEYER E, Building institutions in Kabul in the 1960s. Sites, spaces and architectures of development cooperation. JA 245 (2019) 604-30.

152 BIDDLE M, William the Conqueror's palace in Winchester: the evidence of John Aubrey. JBAA 1721 (2019) 90-4.

153 BLACK C, Economy and community: architecture and demographics of boardinghouses in the southside neighborhood of Lancaster, Pennsylvania, 1880-1920. PH 862 (2019) 222-53.

154 BLAGOJEVIĆ L, An architect's library: printed matter and PO-MO ideas in Belgrade in the 1980s. In KULIĆ V ed, Second world postmodernisms: architecture and society under late socialism. London: Bloomsbury Visual Arts 2019. 62-78.

155 BOCHARNIKOVA D, The NER project: a vision of post-industrial urbanity from post-Stalin Russia. JA 245 (2019) 631-54.

156 BOTTI G, Influences, identity and historiography in Colombia: the reception of Brazilian modernism (1940s-1960s). JA 246 (2019) 731-55.

157 BREEN C, The early Ottomanization of urban Cyprus. PMA 531 (2019) 21-37.

158 CANNADINE D, Westminster Abbey: a church in history. New Haven: Yale University Press 2019. pp 456.

159 COOPER J P D \& GAUNT R A, Architecture and politics in the Palace of Westminster, 1399 to the present. ParlH 381 (2019) 1-16. 
160 DAWOOD A, Building 'brotherhood': John D. Rockefeller Jr and the foundations of New York City's International Student House. JA 247 (2019) 898-924.

161 DE CANALES F G \& LOMBARDERO N A, Aldo Rossi and the architecture of Spanish democratic transition in Seville. JA 241 (2019) 73-90.

162 DEL MAR VALLS M, The painted ceiling of Santa Maria de Llíria and its dancing images. Emus 441 (2019) 25-40.

163 DERIU D, 'A dynamic attitude of the gaze': Gabriele Basilico's sense of vertical space. JA 248 (2019) 1096-117.

164 DESMAREST C G, Princes Street, Edinburgh: a street of encounters. BOEC 151 (2019) 13-28.

165 DRĖMAITE M, Baltic mikroraions and kolkhoz settlements within the Soviet architectural award system. JA 245 (2019) 655-75.

166 FINKE M, 'Building history': Lübeck in the architectural history of the Middle Ages. In JAHNKE C ed, A companion to medieval Lübeck. Leiden: Brill 2019. 93-165.

167 GARRETT B \& KLINKE I, Opening the bunker: function, materiality, temporality. EPC 376 (2019) 1063-81.

168 GOSSEYE J, 'Uneasy bedfellows' conceiving urban megastructures: precarious public-private partnerships in post-war British new towns. PlP 346 (2019) 937-57.

169 HASLAM R, Stephenson's Roundhouse in context: excavations at the Stratford Locomotive and Carriage Works, London Borough of Newham. IAR 411 (2019) 31-44.

170 HAYWOOD E \& SCHMIEDEKNECHT T, Absent architectures: post-war housing in British children's picture books (1960-present). JA 244 (2019) 487-511.

171 HENDEL M \& FILALI N, Architectural forms during the colonial era. Investment property in Oran, 1845-1945. HU 541 (2019) 139-71.

172 HIMES A, The embedded politics of type: Sedad Hakkı Eldem and the Turkish House. JA 246 (2019) $756-77$.

173 HOISINGTON R M, Étienne Fessard's prints of the Chapel of the Hôpital des Enfants Trouvés in Paris. PQ 364 (2019) 404-24.

174 KAPITAIKIN L A, David's dancers in Palermo: Islamic dance imagery and its Christian recontextualization in the ceilings of the Cappella Palatina. Emus 441 (2019) 3-23.

175 LEONE S C, Palace architecture and decoration in early modern Rome. In JONES P M, WISCH B \& DITCHFIELD S eds, A companion to early modern Rome, 1492-1692. Leiden: Brill 2019. 342-66.

176 LEVITT I, 'Give authority': the treasury and the renovation of Holyrood, 1837-1909. BOEC 151 (2019) 45-62.

177 MCKELLAR E, Adapting and anticipating: the home planning consultancy work of Hilde Reiss and Jane Drew, 1943-45. In DARLING E \& WALKER N R eds, Suffragette city: women, politics, and the built environment. Abingdon: Routledge 2019. 139-60.

178 MCWILLIAM R, Fancy repositories: the arcades of London's West End in the nineteenth century. $L J$ 442 (2019) 93-112.

179 MELHUISH C, Aesthetics of social identity: re-framing and evaluating modernist architecture and planning as cultural heritage in Martinique. PLP 342 (2019) 265-83.

180 MILJAČKI A, Cultural feedback loops of late socialism: appropriation and transformation of postmodern tropes for Uran and Crystal in Česká Lípa. In KULIĆ V ed, Second world postmodernisms: architecture and society under late socialism. London: Bloomsbury Visual Arts 2019. 163-79.

181 MORONEY S, Rooms of their own: child experts, house design, and the rise of the child's private bedroom. JFH 442 (2019) 119-44.

182 MUCHADA A, Between modernization and identity: colonial social housing as a specific theoreticopractical corpus of colonial architecture - the case of Tetouan (Morocco, 1912-1956). PlP 344 (2019) 601-20.

183 MUSKETT G, Athena Parthenos in Liverpool. JHelS 1391 (2019) 110-15.

184 PETER B, The impact of the talkies on Scottish cinema architecture. VCB 203 (2019) 202-20.

185 RIVERA F, Incomplete postmodernism: the rise and fall of utopia in Cuba. In KULIĆ V ed, Second world postmodernisms: architecture and society under late socialism. London: Bloomsbury Visual Arts 2019. 128-42.

186 RYAN S, Sligo Gaol. Hire 272 (2019) 47. 
187 SALGIRLI S, Soap bars and silk cocoons: microecologies of connectivity in late medieval Mediterranean architecture. JEMH 23 2-3 (2019) 121-51.

188 SCOTT J B, Roman church architecture: the early modern façade. In JONES P M, WISCH B \& DITCHFIELD S eds, A companion to early modern Rome, 1492-1692. Leiden: Brill 2019. 427-58.

189 SHINKLE E, The city inhabits me: space, topology, and Gabriele Basilico's Milano. Ritratti di fabbriche. JA 248 (2019) 1070-83.

190 SINGLER S \& STERNBERG M, The civic and the sacred: Alvar Aalto's churches and parish centres in Wolfsburg, 1960-68. ArchH 621 (2019) 205-236.

191 SMYTH F, 'A matter of practical emergency': Herbert Baker, Hope Bagenal, and the acoustic legacy of the Assembly Chamber in imperial Delhi. ArchH 621 (2019) 113-44.

192 STINE D, A reconsideration of Michelangelo's unrealised façade for the Basilica of San Lorenzo in Florence. ArchH 621 (2019) 39-67.

193 STOJILJKOVIĆ D M \& IGNJATOVIĆ A, Towards an authentic path: structuralism and architecture in socialist Yugoslavia. JA 246 (2019) 853-76.

194 SWEETEN A R, China's old churches: the history, architecture, and legacy of Catholic sacred structures in Beijing, Tianjin, and Hebei Province. Leiden: Brill 2019. pp xxii +419.

195 TAYLOR J, Amaza's azurest: modern architecture and the 'new negro' woman. In DARLING E \& WALKER N R eds, Suffragette city: women, politics, and the built environment. Abingdon: Routledge 2019. 32-56.

196 TAYLOR M, St Stephen's in war and peace: civil defence and the location of Parliament, 1938-51. ParlH 381 (2019) 135-48.

197 TEETAERT D, BAEYENS N, PERDAEN Y, FIERS G, DE KOCK T, ALLEMEERSCH L, BOUDIN M \& CROMBÉ P, A well-preserved Michelsberg culture domed oven from Kortrijk, Belgium. A 93368 (2019) 342-58.

198 TOMER S L, Beyond the bind: architecture, gendered agency and South African urban struggle. In DARLING E \& WALKER N R eds, Suffragette city: women, politics, and the built environment. Abingdon: Routledge 2019. 182-201.

199 VALTORTA R, Architecture, city, landscape: a conversation with Gabriele Basilico. JA 248 (2019) $1134-48$.

200 WERRONEN S, The rebuilding of Ripon Minster nave, 1503-22. JBAA 1721 (2019) 155-75.

201 WITTE A A, Scale, space, and spectacle: church decoration in Rome, 1500-1700. In JONES P M, WISCH B \& DITCHFIELD S eds, A companion to early modern Rome, 1492-1692. Leiden: Brill 2019. 459-81.

\section{Housing}

202 BOYD G A, 'As easy as plugging in a fire': modernity, morality and the Mespil apartments 1958-72. In WARD B, PIKE M \& BOYD G eds, Irish housing design 1950-1980: out of the ordinary. Abingdon: Routledge 2019. 37-62.

203 CAYER A, Metropolitan living: the Los Angeles Parklebrea apartments. JUH 452 (2019) 354-71.

204 DAVIDI S, From the margins to the center: urban housing for single Jewish women in pre-state Israel. WomHR 291 (2019) 85-110.

205 DELANEY M, The Coombe North: roads, activism and an architecture for Dublin's liberties 19681978. In WARD B, PIKE M \& BOYD G eds, Irish housing design 1950-1980: out of the ordinary. Abingdon: Routledge 2019. 189-213.

206 DONOVAN K, The high life: Ardoyne House, 1962-1967. In WARD B, PIKE M \& BOYD G eds, Irish housing design 1950-1980: out of the ordinary. Abingdon: Routledge 2019. 63-89.

207 GOLDBERG J, Making the house a home in later medieval York. JMH 452 (2019) 162-80.

208 GOLDSTEIN B D, Rehabbing housing, rehabbing people: West 114th Street and the failed promise of housing rehabilitation. $B$ \& $L 262$ (2019) 43-72.

209 GRANGER W, 'Order, convenience, and beauty': the style, space, and multiple narratives of San Felipe Courts. B \& L 261 (2019) 32-47.

210 HESS P M \& LEWIS R, Property rights, redevelopment areas, and Toronto ratepayer associations in the 1950s. JUH 452 (2019) 279-99. 
211 HOLLANDER J, JOHNSON M, DREW R B \& TU J, Changing urban form in a shrinking city. EPB 465 (2019) 963-91.

212 IÑIGO J \& MACE A, The suburban perimeter blocks of Madrid 10 years on: how residents' level of satisfaction relates to urban design qualities. PlP 346 (2019) 999-1021.

213 LAMBE N R \& DONGRE A R, A shape grammar approach to contextual design: a case study of the Pol houses of Ahmedabad, India. EPB 465 (2019) 845-61.

214 MCKELLAR E, All roof, no wall: Peter Boston, a-frames and the primitive hut in twentieth-century British architecture, c. 1890-1970. ArchH 621 (2019) 237-69.

215 MCMANUS R, Tackling the urban housing problem in the Irish Free State, 1922-1940. UH 461 (2019) 62-81.

216 MHEARÁIN A N \& WARD B, The sharp edge of newness: situating the Simmonscourt apartments 1964-1966. In WARD B, PIKE M \& BOYD G eds, Irish housing design 1950-1980: out of the ordinary. Abingdon: Routledge 2019. 90-114.

217 MULROONEY S, Shared vision, shared courtyards: Dundanion Court, Cork 1964-1968. In WARD B, PIKE M \& BOYD G eds, Irish housing design 1950-1980: out of the ordinary. Abingdon: Routledge 2019. 115-33.

218 MURPHY O, The expression of method: six houses at Herbert Road 1976-1979. In WARD B, PIKE M \& BOYD G eds, Irish housing design 1950-1980: out of the ordinary. Abingdon: Routledge 2019. 214-37.

219 RAST J, The origins of the dual city: housing, race, and development in twentieth-century Chicago. Chicago: University of Chicago Press 2019. pp 352.

220 STILES E B, No simple dwelling: design, politics, and the mid-twentieth-century American economy house. B \& L 261 (2019) 79-93.

221 VIOLETTE Z J, Plans and priorities: multifamily housing types and French Canadian builders in northern New England, 1890-1950. B \& L 262 (2019) 17-42.

222 WARD B, An architecture of connections: the Ballybrack Cooperative 1969-72. In WARD B, PIKE M \& BOYD G eds, Irish housing design 1950-1980: out of the ordinary. Abingdon: Routledge 2019. 13459 .

223 WEST D K, The cybernetic eye: scientific planning in the Soviet mikroraion. JA 245 (2019) 699-717.

\section{Heritage and the historic environment}

224 ANNUZIATA S, Garbatella: heritage, gentrification, and public policies in Rome, Italy. In SIES M C, GOURNAY I \& FREESTONE R eds, Iconic planned communities and the challenge of change. Philadelphia: University of Pennsylvania Press 2019. 197-216.

225 ARKARAPRASERTKUL N, Gentrifying heritage: how historic preservation drives gentrification in urban Shanghai. IJHerS 259 (2019) 882-96.

226 AYKAÇ P, Musealisation as a strategy for the reconstruction of an idealised Ottoman past: Istanbul's Sultanahmet district as a 'museum-quarter'. IJHerS 252 (2019) 160-77.

227 BARAM U, Gentrification and nostalgia: archaeology of memory for the segregated past in a coastal Florida city. IJHerS 257 (2019) 722-35.

228 BEEKSMA A \& DE CESARI C, Participatory heritage in a gentrifying neighbourhood: Amsterdam's Van Eesteren Museum as affective space of negotiations. IJHerS 259 (2019) 974-91.

229 BRIDGE C, Reading the Australian War Memorial, Hyde Park Corner, London. LJ 443 (2019) 22732.

230 CAPPELLINI P, Trading old masters in Florence 1890-1914: heritage protection and the Florentine art trade in Post-Unification Italy. JHC 312 (2019) 363-71.

231 CHLOUPEK B R, Public memory and political street names in Košice: Slovakia's multiethnic second city. JHG 641 (2019) 25-35.

232 COLLINS J F, Vital properties and Afro-Brazilian lives: on promiscuities of gentrification and personhood in Salvador, Bahia's Pelourinho Historical Center. IJHerS 259 (2019) 870-81.

233 CUBITT R S, HARTLE R, MARSHALL M, RICHARDSON B \& ALLISON E, An important 16th century finds assemblage from 'Moorfields', Liverpool Street, London. PMA 532 (2019) 225-65.

234 DE CESARI C \& DIMOVA R, Heritage, gentrification, participation: remaking urban landscapes in the name of culture and historic preservation. IJHerS 259 (2019) 863-9. 
235 DE OLIVEIRA P L S, Imagining an old city in nineteenth-century France: urban renovation, civil society, and the making of Vieux Lyon. JUH 451 (2019) 67-98.

236 DE PIERI F, Questioning public histories of urban planning: an investigation of 'urbanisme horloger' narratives in the Unesco site of Le Locle/La Chaux-de-Fonds. PLP 342 (2019) 335-44.

237 DIMOVA R, Elusive centres of a Balkan city: Skopje between undesirable and reluctant heritage. IJHerS 259 (2019) 958-73.

238 ESPOSITO A \& FAUVEAUD G, The atomization of heritage politics in post-colonial cities: the case of Phnom Penh, Cambodia. EPC 374 (2019) 670-88.

239 FINNERAN N, LICHTENSTEIN R \& WELCH C, Place, space and memory in the Old Jewish East End of London: an archaeological biography of Sandys Row Synagogue, Spitalfields and its wider context. IJHA 232 (2019) 380-403.

240 GARNAUT C \& FREESTONE R, Colonel light gardens: history, heritage, and the enduring suburb in Adelaide, South Australia. In SIES M C, GOURNAY I \& FREESTONE R eds, Iconic planned communities and the challenge of change. Philadelphia: University of Pennsylvania Press 2019. 132-55.

241 GINZARLY M, HOUBART C \& TELLER J, The historic urban landscape approach to urban management: a systematic review. IJHerS 2510 (2019) 999-1019.

242 GÓRNY J \& GÓRNA A, After decolonization: changes in the urban landscape of Platô in Praia, Cape Verde. JUH 456 (2019) 1103-30.

243 GROOP K, Undoing GDR iconoclasm: the return and interpretation of a spiritual and academic heritage through the building of the Paulinum in Leipzig. ChH 884 (2019) 1013-38.

244 HOU S, Remembering trees as heritage: Guji discourse and the meaning-making of trees in Hangzhou, Qing China. IJHerS 255 (2019) 455-68.

245 HULME T \& DE SOUZA SANTOS A, Cultural marginality and urban place making: the case of Leicester and Ouro Preto. In SLATER T \& CUPPLES J eds, Reproducing and contesting urban marginality: comparative and interdisciplinary dialogues. London: Rowman \& Littlefield 2019. 143-60.

246 ISAKHAN B \& MESKELL L, UNESCO's project to 'Revive the Spirit of Mosul': Iraqi and Syrian opinion on heritage reconstruction after the Islamic State. IJHerS 2511 (2019) 1189-204.

247 JEON C \& KANG Y, Restoring and re-restoring the Cheonggyecheon: nature, technology, and history in Seoul, South Korea. EnH 244 (2019) 736-65.

248 JETHRO D, Liberated waste: heritage and materiality at Robben Island and Constitution Hill, South Africa. IJHerS 253 (2019) 259-76.

249 JOYCE S, Media tourism and conflict heritage in Dubrovnik, Westeros. JPopC 526 (2019) 1387-407.

250 KAASIK-KROGERUS S, Politics of mobility and stability in authorizing European heritage: Estonia's Great Guild Hall. In LÄHDESMÄKI T, PASSERINI L, KAASIK-KROGERUS S \& VAN HUIS I eds, Dissonant heritages and memories in contemporary Europe. London: Palgrave Macmillan 2019. 157-81.

251 KAHRAMAN G \& CARTER R, Adaptation of heritage architecture in Al Asmakh, Doha: insights into an urban environment of the Gulf. PMA 531 (2019) 38-65.

252 KELLY D \& O'KEEFFE T, A new world man in an old world town: the identification of Sir Walter Raleigh's residence in late sixteenth-century Youghal, Co. Cork, Ireland. IJHA 231 (2019) 1-33.

253 KING C, Early fabric in historic towns: timber-framed buildings in Southwell, Nottinghamshire, $c$. 1350-1650. VA 501 (2019) 18-39.

254 KING R \& LERTNAPAKUN P, Ambiguous heritage and the place of tourism: Bangkok's Rattanakosin. IJHerS 253 (2019) 298-311.

255 LEESON L, Our land: creative approaches to the redevelopment of London's Docklands. IJHerS 254 (2019) 365-79.

256 LESH J P, From modern to postmodern skyscraper urbanism and the rise of historic preservation in Sydney, Melbourne, and Perth, 1969-1988. JUH 451 (2019) 126-49.

257 LESH J P, The National Estate (and the city), 1969-75: a significant Australian heritage phenomenon. IJHerS 252 (2019) 113-27.

258 MADGIN R, A place for urban conservation? The changing values of Glasgow's built heritage. In KINTREA K \& MADGIN R eds, Transforming Glasgow: beyond the post-industrial city. Bristol: Policy Press 2019. 221-38.

259 MARTÍNEZ P G, From verifiable authenticity to verisimilar interventions: Xintiandi, Fuxing SOHO, and the alternatives to built heritage conservation in Shanghai. IJHerS 2510 (2019) 1055-72. 
260 MASON P, CHAPMAN A \& UNWIN J, Excavations on the site of the Portobello Cutlery Works and adjacent court housing, Sheffield. YAJ 911 (2019) 71-110.

261 NICGHABHANN N, 'A development of practical Catholic Emancipation': laying the foundations for the Roman Catholic urban landscape, 1850-1900. UH 461 (2019) 44-61.

262 PANETTA C, An 'alternative framework for development:' state-citizen relations, urban revitalization, and Downtown Cairo's passageways. IJHerS 259 (2019) 926-42.

263 PETTERSON A, The monumental landscape from below: public statues, popular interaction and nationalism in late nineteenth-century Amsterdam. UH 464 (2019) 722-46.

264 PORTER L, JACKSON S \& JOHNSON L, Remaking imperial power in the city: the case of the William Barak building, Melbourne. EPD 376 (2019) 1119-37.

265 PROSSER L, The Great Pagoda at Kew: colour and technical innovation in chinoiserie architecture. ArchH 621 (2019) 69-88.

266 PUZON K, Saving Beirut: heritage and the city. IJHerS 259 (2019) 914-25.

267 RADIS U, The earliest use of brickwork in Lübeck's secular buildings: new findings of excavations 2009-2014. In JAHNKE C ed, A companion to medieval Lübeck. Leiden: Brill 2019. 66-92.

268 RUSU M S, Shifting urban namescapes: street name politics and toponymic change in a Romanian (ised) city. JHG 651 (2019) 48-58.

269 SANTOS P M, Tourism and the critical cosmopolitanism imagination: 'the worst tours' in a European world heritage city. IJHerS 259 (2019) 943-57.

270 SANTOS R D C M, Undocumented objects: the collection Cavalcanti at Museum Volkenkunde, Leiden. MuHJ 121 (2019) 7-28.

271 SAUNDERS N, FROLIK J \& HEYD V, Zeitgeist archaeology: conflict, identity and ideology at Prague Castle, 1918-2018. A 93370 (2019) 1009-25.

272 SILVER C, Menteng: heritage of a planned community in a Southeast Asian megacity. In SIES M C, GOURNAY I \& FREESTONE R eds, Iconic planned communities and the challenge of change. Philadelphia: University of Pennsylvania Press 2019. 111-31.

273 SIMON V K \& BRAATHEN E, Collective heritage and urban politics: an uncertain future for the living culture of Rio de Janeiro? IJHerS 254 (2019) 380-94.

274 UNDERWOOD D R, (Re)using ruins: public building in the cities of the late antique West, A.D. 300600. Leiden: Brill 2019. pp xvi +269.

275 VILLAR J G \& VICENCIO F C, Social emotions, heritage and recognition. The struggle of Colina stonemasons in Santiago, Chile. IJHerS 2512 (2019) 1263-79.

276 WEKSLER-BDOLAH S, Aelia Capitolina - Jerusalem in the Roman period: in light of archaeological research. Leiden: Brill 2019. pp xxvi +244.

277 WOOLHOUSE T, HINMAN M \& SUDDS B, Recent discoveries at Ely Cathedral, Cambridgeshire: Aetheldreda's Gate, the church of Holy Cross and the possible boundary of the Anglo-Saxon monastery. AJ 1761 (2019) 159-95.

\section{Social structure}

\section{Research methods, aids and materials}

278 FRENKEL M \& YAGUR M, Jewish communal history in geniza scholarship: part 1, from early beginnings to Goiten's magnum opus. JeH 32 2-4 (2019) 131-42.

279 KOWALESKI M, Appendix: an annotated list of printed or online transcriptions and translations of medieval town courts in Britain to 1500. In GODDARD R \& PHIPPS T eds, Town courts and urban society in late medieval England, 1250-1500. Woodbridge: Boydell \& Brewer 2019. 220-35.

\section{Social organization, clubs and societies}

280 ASHITA S, Social ties and local societies in modern Japanese cities. Residents' associations and disadvantaged workers in pre-War Ōsaka. HU 552 (2019) 57-79.

281 BERRY H, Orphans of empire: the fate of London's foundlings. Oxford: Oxford University Press 2019. pp 384 . 
282 ESPOSITO A, 'Charitable' assistance between lay foundations and pontifical initiatives. In JONES P M, WISCH B \& DITCHFIELD S eds, A companion to early modern Rome, 1492-1692. Leiden: Brill 2019. 199-213.

283 HINKS P P, 'Perfectly proper and conciliating': Jean-Pierre Boyer, freemasonry, and the revolutionary Atlantic in eastern Connecticut, 1800-1801. AtlSt 163 (2019) 364-85.

284 INGRAM D, Imagining animal rights in nineteenth-century New York: satire and strategy in the animal protection movement. JHS 322 (2019) 244-57.

285 MAUDLIN D, The urban inn: gathering space, hierarchy and material culture in the eighteenthcentury British town. UH 464 (2019) 617-48.

286 MEDINA D E L, 'Para el aumento del servicio de Dios [for the intensification of service to God]': formalization of piety and charity in Lima's confraternities during the 16th and 17th centuries. In ENGEL E A ed, A companion to early modern Lima. Leiden: Brill 2019. 253-74.

287 NAOKI I, Modernisation of the chō of Ōsaka. HU 552 (2019) 35-56.

288 ÖNNERFORS A, Atlantic antagonism: revolution and race in German-American Masonic relations, 1848-1861. AtlSt 163 (2019) 386-404.

289 RAMON M, 'A local habitation and a name': the Dublin Mechanics' Institute and the evolution of Dublin's public sphere, 1824-1904. IESH 461 (2019) 22-45.

290 WILKINS C L, Patterns of leadership in the guilds of 17th-century Aleppo. In WINTER S \& ADE M eds, Aleppo and its hinterland in the Ottoman period/Alep et sa province à l'époque ottomane. Leiden: Brill 2019. 62-85.

\section{Class structure}

291 BALDWIN J W, Knights, lords, and ladies: in search of aristocrats in the Paris region, 1180-1220. Philadelphia: University of Pennsylvania Press 2019. pp 432.

292 CHERRY H, Down and out in Saigon: stories of the poor in a colonial city. New Haven: Yale University Press 2019. pp 280.

293 HIGGS D, Ultraroyalism in Toulouse: from its origins to the revolution of 1830. Baltimore, MD: Johns Hopkins University Press 2019. pp 242.

294 LUSTIG E \& LUSTIG T, Losing ground: decline of Angkor's middle-level officials. JSEAS 502 (2019) 409-30.

295 REICK P, Desire or displacement? Working-class notions of urban belonging in late-nineteenth-century Germany. JUH 456 (2019) 1193-211.

\section{Social life}

296 ARNOLD T J, Gaining strength from nature: surviving war in Munich. In LAAKKONEN S, MCNEILL J R, TUCKER R P \& VUORISALO T eds, The resilient city in World War II: urban environmental histories. London: Palgrave Macmillan 2019. 127-50.

297 BEAVAN L, Elite patronage and collecting. In JONES P M, WISCH B \& DITCHFIELD S eds, A companion to early modern Rome, 1492-1692. Leiden: Brill 2019. 387-411.

298 CAVAZZINI P, Middle-class patronage, collecting, and the art market. In JONES P M, WISCH B \& DITCHFIELD S eds, A companion to early modern Rome, 1492-1692. Leiden: Brill 2019. 412-26.

299 FROHARDT-LANE S, Imagined resilience: U.S. conservation campaigns and far salvage. In LAAKKONEN S, MCNEILL J R, TUCKER R P \& VUORISALO T eds, The resilient city in World War II: urban environmental histories. London: Palgrave Macmillan 2019. 81-102.

300 HEWITT M, Making social knowledge in the Victorian city: the visiting mode in Manchester, 18321914. Abingdon: Routledge 2019. pp 114.

301 JAHNKE C, Lübeck's confraternities. In JAHNKE C ed, A companion to medieval Lübeck. Leiden: Brill 2019. 372-97.

302 JONES R, Maria Russell and Syed Ameer Ali: family, opportunity and an inter-racial relationship in Victorian London. FCH 223 (2019) 181-99.

303 KLUGMAN M \& RICATTI F, Re-creating home and exploring away in new cities: Italian migration and football codes within Australian urban centres. IJHS 366 (2019) 513-31.

304 MENEGHIN A, The social fabric of fifteenth-century Florence: identities and change in the world of second-hand dealers. Abingdon: Routledge 2019. pp 238. 
305 MONTRIE C, 'A bigoted, prejudiced, hateful little area': the making of an all-white suburb in the deep north. JUH 452 (2019) 300-20.

306 ROMANO D, Patricians and popolani: the social foundations of the Venetian Renaissance state. Baltimore, MD: Johns Hopkins University Press 2019. pp 242.

307 ROTELLA C, The world is always coming to an end: pulling together and apart in a Chicago neighborhood. Chicago: University of Chicago Press 2019. pp 320.

308 RUVOLDT M, Gossip and reputation in sixteenth-century Rome: Tommaso de'Cavalieri and Lavinia della Valle. RS 343 (2019) 374-91.

309 SALZBERG R, Mobility, cohabitation and cultural exchange in the lodging houses of early modern Venice. UH 463 (2019) 398-418.

310 TORREBADELLA-FLIX X, RIVERO-HERRAIZ A \& SÁNCHEZ-GARCÍA R, When the elites began going to the gym: the professional and social spaces of the first hygienic gymnasiums in Madrid, 1860-69. IJHS 36 15-16 (2019) 1347-71.

\section{Social life, customs and traditions}

311 FALCK S T, Remembering Dixie: the battle to control historical memory in Natchez, Mississippi. Jackson: University Press of Mississippi 2019. pp 374.

312 GIBBS G G, Five parishes in late medieval and Tudor London: communities and reforms. Abingdon: Routledge 2019. pp 206.

313 SAHIN E, Sandcastles, ball games, and scooters: unearthing children's play in the public parks of interwar Paris. HR/RH 452 (2019) 28-46.

314 SCRIBNER V, Inn civility: urban taverns and early American civil society. New York: New York University Press 2019. pp 304.

315 SUR R K, Transformation and decline of Sawng: the socio-cultural effects of migration and the changes in intercommunity relations in Calcutta c. 1870-1930. IESHR 564 (2019) 387-409.

\section{Religion}

316 ALLEMANN D S, Empire and the right to preach the gospel in the School of Salamanca, 1535-1560. HJ 621 (2019) 35-55.

317 AMANIK A, Dust to dust: a history of Jewish death and burial in New York. New York: New York University Press 2019. pp 272.

318 ARON-BELLER K, Ghettoization: the papal enclosure and its Jews. In JONES P M, WISCH B \& DITCHFIELD S eds, A companion to early modern Rome, 1492-1692. Leiden: Brill 2019. 232-46.

319 BURGESS C, 'According to his wise discretion': civic Catholicism in fifteenth-century Bristol - and beyond. HR 92257 (2019) 479-99.

320 CLARKE A, The so-called London Baptist Education Society of 1752 - some further explorations. $B Q$ 503 (2019) 86-105.

321 DAVIES P, Saving the soul of Giovanni di Bicci de' Medici: function and design in the old sacristy of San Lorenzo. ArchH 621 (2019) 1-37.

322 DE GOEY F, The Dutch consul J.A. Kruyt and the policing of Muslim pilgrims in Jeddah, c. 1858-88. In SUONPÄÄ M \& WRIGHT O eds, Diplomacy and intelligence in the nineteenth-century Mediterranean world. London: Bloomsbury Academic 2019. 133-56.

323 DITCHFIELD S, Romanus and Catholicus: counter-reformation Rome as Caput Mundi. In JONES P M, WISCH B \& DITCHFIELD S eds, A companion to early modern Rome, 1492-1692. Leiden: Brill 2019. 131-47.

324 FOLEY D, 'Too many children?' Family planning and Humanae Vitae in Dublin, 1960-72. IESH 461 (2019) 142-60.

325 FOURIE J \& INWOOD K, Interracial marriages in twentieth-century Cape Town: evidence from Anglican marriage records. HF 243 (2019) 629-52.

326 GOLDBERG J, The priest of Nottingham and the holy household of Ousegate: telling tales in court. In GODDARD R \& PHIPPS T eds, Town courts and urban society in late medieval England, 12501500. Woodbridge: Boydell \& Brewer 2019. 60-76.

327 GRAßMANN A, Between reclusion and integration: monasteries and convents in medieval Lübeck. In JAHNKE C ed, A companion to medieval Lübeck. Leiden: Brill 2019. 185-225. 
328 GUAZZELLI G A, Roman antiquities and Christian archaeology. In JONES P M, WISCH B \& DITCHFIELD S eds, A companion to early modern Rome, 1492-1692. Leiden: Brill 2019. 530-45.

329 HUNT J M, Ritual time and popular expectations of papal rule in early modern Rome. ERC 451 (2019) 29-49.

330 HUNT J M, Rome and the vacant See. In JONES P M, WISCH B \& DITCHFIELD S eds, A companion to early modern Rome, 1492-1692. Leiden: Brill 2019. 99-114.

331 JACOB W M, 'The glory of the age we live in': Christian education and philanthropy in eighteenthcentury London charity schools. SCH 551 (2019) 241-55.

332 JONES P M, Celebrating new saints in Rome and across the globe. In JONES P M, WISCH B \& DITCHFIELD S eds, A companion to early modern Rome, 1492-1692. Leiden: Brill 2019. 148-66.

333 KAHLENBERG C, The star of David in a cedar tree: Jewish students and Zionism at the American University of Beirut (1908-1948). MES 554 (2019) 570-89.

334 KUNTZ M A, Liturgical, ritual, and diplomatic spaces at St. Peter's and the Vatican Palace: the innovations of Paul IV, Urban VIII and Alexander VII. In JONES P M, WISCH B \& DITCHFIELD S eds, A companion to early modern Rome, 1492-1692. Leiden: Brill 2019. 75-98.

335 LEGG S, A pre-partitioned city? Anti-colonial and communal Mohallas in inter-war Delhi. SAs 421 (2019) 170-87.

336 LUXFORD J, Recording and curating relic at Westminster Abbey in the late Middle Ages. JMH 452 (2019) 204-30.

337 MCCLUSKY K E, New saints in late-mediaeval Venice, 1200-1500: a typological study. Abingdon: Routledge 2019. pp 254.

338 MCFARLAND J, Relics, reinvention, and reform in Renaissance Venice: Catherine of Siena's stigmata at the Basilica dei Santi Giovanni e Paolo. RS 342 (2019) 278-302.

339 MCGRATH P, Secular power, sectarian politics: the American-born Irish elite and Catholic politic culture in nineteenth-century New York. JAEH 383 (2019) 36-75.

340 MAIR L M, They 'come for a lark': London ragged school union teaching advice in practice, 1844-70. SCH 551 (2019) 324-46.

341 MASTERS B, The millet wars in Aleppo, 1726-1821: an Ottoman perspective. In WINTER S \& ADE $\mathrm{M}$ eds, Aleppo and its hinterland in the Ottoman period/Alep et sa province à l'époque ottomane. Leiden: Brill 2019. 130-51.

342 MORGAN A, The Philadelphia riots of 1844: republican Catholicism and Irish Catholic apologetics. PH 861 (2019) 86-102.

343 PARKER E, Learning in Lincoln. HT 691 (2019) 106-7.

344 PATTENDEN M, The Roman curia. In JONES P M, WISCH B \& DITCHFIELD S eds, A companion to early modern Rome, 1492-1692. Leiden: Brill 2019. 44-59.

345 PURVIS Z, Religion, revolution, and the dangers of demagogues: the Basel 'troubles' (wirren) and the politics of Protestantism, 1830-1833. ChH 882 (2019) 409-39.

346 SALCEDO J-C, Guadalupe, Spain: the organic growth of a monastery and the morphology of a medieval village. JUH 453 (2019) 542-56.

347 SCLAR D, A communal tree of life: Western Sephardic Jewry and the library of the Ets Haim Yesiba in early modern Amsterdam. BookH 221 (2019) 43-65.

348 SLATTER R, Materiality and the extended geographies of religion: the institutional design and everyday experiences of London's Wesleyan Methodist circuits, 1851-1932. JHG 641 (2019) 60-71.

349 STEWART Z, A lesson in patronage: King Henry III, the Knights Templar, and a royal mausoleum at the Temple Church in London. Spec 942 (2019) 334-84.

350 THOMSON A, The revival of a diocese: the role of Bishop Morley at Worcester 1660-62. MidH 441 (2019) 56-70.

351 VAN BRUANE A-L, The last chapter of the golden fleece (Ghent, 1559). Burgundian ritual, church space and urban Lieux de Mémoire. DC 431 (2019) 7-26.

352 VOGELER H \& FREYTAG H, Art, belief, and calculation: on the churches and Christian endowments of medieval Lübeck. In JAHNKE C ed, A companion to medieval Lübeck. Leiden: Brill 2019. 273-305.

353 VOßHALL A, A matter of distance? The bishops and the city of Lübeck in the late Middle Ages. In JAHNKE C ed, A companion to medieval Lübeck. Leiden: Brill 2019. 166-84.

354 WALLACE V, Sectarianism and separatism in colonial Port Phillip. JCCH 203 (2019) 1-26. 
355 WILD M, Renewal: liberal Protestants and the American city after World War II. Chicago: University of Chicago Press 2019. pp 336.

356 WISCH B, Building brotherhood: confraternal piety, patronage, and place. In JONES P M, WISCH B \& DITCHFIELD S eds, A companion to early modern Rome, 1492-1692. Leiden: Brill 2019. 214-31.

357 WOBICK-SEGEV S E, Negotiated places: making Jewish space in postwar East Berlin. GeH 374 (2019) 540-59.

358 ZIPF C W, Neo-Solomonic palladianism: Touro Synagogue and its women's balcony, Newport, Rhode Island. EAmS 174 (2019) 572-89.

\section{Recreation}

359 BROCHARD T, Cachepell and tennis in Edinburgh in the sixteenth and seventeenth centuries. BOEC 151 (2019) 109-18.

360 CHANCE H, Chocolate heaven: productive consumption and corporate power in the recreational landscapes of Cadbury, Bournville and Hershey, Pennsylvania in the early twentieth century. SHGD 391 (2019) 22-39.

361 CRAWFORD D M, Paper-gate: the Philadelphia Bell and the 'scandal' that brought down the World Football League. PH 864 (2019) 457-73.

362 KIDAMBI P, Cricket country: an Indian odyssey in the age of empire. Oxford: Oxford University Press 2019. pp 448.

363 REES B, Sport, class and identity at Swansea, 1870-1914. WHR 294 (2019) 594-623.

\section{Social problems and deviance}

364 ADLER J S, Murder in New Orleans: the creation of Jim Crow policing. Chicago: University of Chicago Press 2019. pp 280.

365 ANDERSON C, Convicts, commodities, and connections in British Asia and the Indian Ocean, 1789-1866. IRSH 64 S27 (2019) 205-27.

366 BERGLUND M, Contentious spaces: urban arenas for violent crowds in pre-industrial Stockholm, c. 1700-1850. In CHALUS E \& KAARTINEN M eds, Gendering spaces in European towns, 15001914. Abingdon: Routledge 2019. 154-69.

367 BERNSTEIN D, Justice in plain sight: how a small-town newspaper and its unlikely lawyer opened America's courtrooms. Lincoln, NE: University of Nebraska Press 2019. pp 280.

368 BUKEY E B, Juvenile crime and dissent in Nazi Vienna, 1938-1945. London: Bloomsbury Academic 2019. pp 208.

369 COHEN E S \& COHEN T V, Justice and crime. In JONES P M, WISCH B \& DITCHFIELD S eds, $A$ companion to early modern Rome, 1492-1692. Leiden: Brill 2019. 115-30.

370 COX C \& MARLAND H, 'Unfit for reform or punishment': mental disorder and discipline in Liverpool Borough Prison in the late nineteenth century. SH 442 (2019) 173-201.

371 CUENCA E L, Borough court cases as legal precedent in English town custumals. In GODDARD R \& PHIPPS T eds, Town courts and urban society in late medieval England, 1250-1500. Woodbridge: Boydell \& Brewer 2019. 43-59.

372 GOSSARD J M, Breaking a child's will: eighteenth-century Parisian juvenile detention centers. FHS 422 (2019) 239-59.

373 HONORES R, Lima: a legal city in the early colonial Andes (1538-1600). In ENGEL E A ed, A companion to early modern Lima. Leiden: Brill 2019. 127-45.

374 KAMP J, Crime, gender and social control in early modern Frankfurt am Main. Leiden: Brill 2019. pp $\mathrm{xii}+335$.

375 KOWALESKI M, Town courts in medieval England: an introduction. In GODDARD R \& PHIPPS T eds, Town courts and urban society in late medieval England, 1250-1500. Woodbridge: Boydell \& Brewer (2019) 43-59.

376 KRIMSTI F, Disciplining disobedient subjects: the punishment of Aleppo's insurgents in 1850 as a contentious issue. In WINTER S \& ADE M eds, Aleppo and its hinterland in the Ottoman period/ Alep et sa province à l'époque ottomane. Leiden: Brill 2019. 204-28.

377 LIAPI L, Roguery in print: crime and culture in early modern London. Woodbridge: Boydell \& Brewer 2019. pp x +197 . 
378 LIEDL J, Transience and impoverished London mothers, 1674-1750. EMW 141 (2019) 76-84.

379 MADDOCK S, Society, status and the leet court in Margery Kempe's Lynn. In GODDARD R \& PHIPPS T eds, Town courts and urban society in late medieval England, 1250-1500. Woodbridge: Boydell \& Brewer 2019. 200-19.

380 MOSS E, Night raiders: burglary and the making of modern urban life in London, 1860-1968. Oxford: Oxford University Press 2019. pp 272.

381 OGDEN J, Innocent children and passive pederasts: sodomy, age of consent, and the legal and juridical vulnerability of boys in Buenos Aires, 1853-1912. L \& HR 371 (2019) 237-74.

382 OJO A \& OJEWALE O, Urbanisation and crime in Nigeria. London: Palgrave Macmillan 2019. pp $\mathrm{xxviii}+247$.

383 PINTO A B \& ERICSSON M, 'Youth riots' and the concept of contentious politics in historical research: the case of the 1948 Stockholm Easter Riots. SJH 441 (2019) 1-26.

384 SAGUI S, The business of the leet courts in medieval Norwich, 1288-1391. In GODDARD R \& PHIPPS T eds, Town courts and urban society in late medieval England, 1250-1500. Woodbridge: Boydell \& Brewer 2019. 117-35.

385 TALLAKSEN A R, Junkies and Jim Crow: the Boggs Act of 1951 and the racial transformation of New Orleans' heroin market. JUH 452 (2019) 230-46.

386 VRINTS A, The theatre of the street: public violence in Antwerp during the first half of the twentieth century. Leiden: Brill 2019. pp 442.

387 WALTER J, A foolish commotion of youth'? Crowds and the 'crisis of the 1590s' in London. LJ 441 (2019) 17-36.

388 WHELAN R, The Colleen Bawn and tourism in Killarney. Hire 271 (2019) 16-19.

\section{Social reforms and improvement}

389 BRADLEY S, Welcoming the New Poor Law: the Bromsgrove Poor Law Union, 1836-1847. FCH 223 (2019) 200-21.

390 CIANI K E, Choosing to care: a century of childcare and social reform in San Diego, 1850-1950. Lincoln, NE: University of Nebraska Press 2019. pp 342.

391 CROOK T, Model institutions and the geography of social reform in early Victorian Britain. HJ 623 (2019) 789-812.

392 WALKER A, All spirits are roused: the 1822 antislavery revolution in Haitian Santo Domingo. SaA 40 3 (2019) 583-605.

\section{Minority groups}

393 ALAGIRISAMY D, Toddy, race, and urban space in colonial Singapore, 1900-59. MAsS 535 (2019) 1675-99.

394 BAYOR R H, Neighbors in conflict: the Irish, Germans, Jews, and Italians of New York City, 19291941. Baltimore, MD: Johns Hopkins University Press 2019. pp 252.

395 BEAUJON D, Policing colonial migrants: the Brigade Nord-Africaine in Paris, 1923-1944. FHS 424 (2019) 655-80.

396 BONATTI V \& GILLE Z, Changing registers of visibility: immigrant labor and waste work in Naples, Italy. ILWCH 951 (2019) 114-29.

397 BRANDON P, Between the plantation and the port: racialization and social control in eighteenthcentury Paramaribo. IRSH 64 S27 (2019) 95-124.

398 BRENNER R F, A remarkable 'emotional community' of rescuers in occupied Warsaw: the cases of Zofia Kossak and Jarosław and Anna Iwaszkiewicz. JGR 213 (2019) 398-417.

399 BURRELL J, The civil rights theatre movement in New York, 1939-1966. London: Palgrave Macmillan 2019. pp xv +236 .

400 BUTTERS JR G R, Normalizing black spectatorship in the Loop: the Roosevelt Theater and black Chicago audiences, 1966-1969. JPopC 564 (2019) 752-72.

401 CILLI A L, The pursuit of happiness: racial utilitarianism and black reform efforts in John T. Clark's Urban League. JUH 451 (2019) 6-22.

402 DAELEN V V, Living together in the 'Yidishe Gas': the case of Antwerp. JGR 213 (2019) 436-55. 
403 DAWLEY E N, Becoming Taiwanese: ethnogenesis in a colonial city, 1800s to 1950s. Cambridge MA: Harvard University Press 2019. pp 426.

404 DAWSON V P, Protection from undesirable neighbors: the use of deed restrictions in Shaker Heights, Ohio. JPH 182 (2019) 116-36.

405 DE LA ROSA A C, Don Juan de Padilla y Pastrana (1596-1670), advocate of Peru's indigenous population? In ENGEL E A ed, A companion to early modern Lima. Leiden: Brill 2019. 146-69.

406 DI TARANTO N, Phoenix and the fight over the Papago-Inner Loop: race, class, and the making of a suburban metropolis. JUH 452 (2019) 211-29.

407 EDWARDS M L, Pittsburgh's Freedom House Ambulance Service: the origins of emergency medical services and the politics of race and health. JHMAS 744 (2019) 440-66.

408 EKHOLM L K, Jews, second-hand trade and upward economic mobility: introducing the ready-to-wear business in industrializing Helsinki, 1880-1930. BuH 611 (2019) 73-92.

409 FLOWE D J, 'Fighting and cutting and shooting, and carrying on': saloons, dives, and the black 'tough' in Manhattan's Tenderloin, 1890-1917. JUH 455 (2019) 925-40.

410 GALIMI V, A microcosm in Florence: Jewish-Gentile interactions from the Fascist regime to the Holocaust. JGR 213 (2019) 359-77.

411 GOMEZ S, The politics of Afro-Asian intimacies in Jim Crow Tokyo. JAEH 391 (2019) 35-65.

412 GÓMEZ X A, Fashioning Lima's Virgin of Copacabana: indigenous strategies of negotiation in the colonial capital. In ENGEL E A ed, A companion to early modern Lima. Leiden: Brill 2019. 337-59.

413 GORDON C, Citizen Brown: race, democracy, and inequality in the St. Louis suburbs. Chicago: University of Chicago Press 2019. pp 216.

414 GOREN T, The destruction of old Jaffa in 1936 and the question of the Arab refugees. MES 556 (2019) 1005-19.

415 GREENIDGE A \& GAHMAN L, Roots, rhizomes and resistance: remembering the Sir George Williams student uprising. $R$ \& $C 612$ (2019) 27-42.

416 GUROCK J S, Parkchester: a Bronx tale of race and ethnicity. New York: New York University Press 2019. pp 304.

417 HALPIN D P, A brotherhood of liberty: black reconstruction and its legacies in Baltimore, 1865-1920. Philadelphia: University of Pennsylvania Press 2019. pp 248.

418 HARRIS D A, The Centre d'Accueil Nord-Africain: social welfare and the 'problem' of Muslim youth in Marseille, 1950-1975. FH 333 (2019) 444-70.

419 HINES T R, Community prejudice is also to blame: significant causes and effects of residential segregation in St. Louis. JUH 453 (2019) 578-94.

420 HOLLAND D, Toffee men, travelling drapers and black-market perfumers - South Asian networks of petty trade in early twentieth century Britain. TCBH 302 (2019) 145-73.

421 HUNDERT G D, The Jews in a Polish private town: the case of Opatow in the eighteenth century. Baltimore, MD: Johns Hopkins University Press 2019. pp 262.

422 HUNG C, Sanctuary squats: the political contestations of Piazza Indipendenza refugee occupiers. RHR 1353 (2019) 119-37.

423 KHAN F, Apartheid mountaineering: race, politics, and the history of the University of Cape Town Mountain and Ski Club, 1933-1969. IJHS 361 (2019) 48-66.

424 LANGROGNET F, Interethnic resentment of mundane grudges? A 1900 Paris fight under the microscope. I \& $M 37$ 1-2 (2019) 24-43.

425 LÔNČÍKOVÁ M, Atrocities in the borderland: anti-Semitic violence in eastern Slovakia (1945-1946). EurRH 266 (2019) 928-46.

426 MÜNCH O, Risky business at Rag Fair. On interreligious relations in the mean streets of early Victorian London. I \& $M 37$ 1-2 (2019) 1-23.

427 ORDAZ J, Protesting conditions inside El Corralón: immigration detention, state repression, and transnational migrant politics in El Centro, California. JAEH 382 (2019) 65-93.

428 PACYGA D A, American Warsaw: the rise, fall, and rebirth of Polish Chicago. Chicago: University of Chicago Press 2019. pp 296.

429 QURAISHI U, Racial calculations: Indian and Pakistani immigrants in Houston, 1960-1980. JAEH 384 (2019) 55-76.

430 RAMOS G, Indigenous populations in early Lima: origins, possessions, and networks. In ENGEL E A ed, A companion to early modern Lima. Leiden: Brill 2019. 196-215. 
431 REED K, 'The prison, by God, where I have found myself: graffiti at Ellis Island immigration station, New York, c. 1900-1923. JAEH 383 (2019) 5-35.

432 REGALADO P A, The Washington Heights uprising of 1992: Dominican belonging and urban policing in New York City. JUH 455 (2019) 961-86.

433 RESTIFO S J, ROSCIGNO V J \& PHILLIPS L A, Racial/ethnic hierarchy and urban labor market inequality: four poignant historical cases. CitC 182 (2019) 662-88.

434 SAMSON M G M, Off-white, on-stage: Jewish self-representation at Chicago's 1933-1934 world's fair. JHG 651 (2019) 9-18.

435 SCHOFIELD C \& JONES B, 'Whatever community is, this is not it': Notting Hill and the reconstruction of 'race' in Britain after 1958. JBS 581 (2019) 142-73.

436 SEMERDJIAN E, Armenians in the production of urban space in early modern Judayda, Aleppo. In WINTER S \& ADE M eds, Aleppo and its hinterland in the Ottoman period/Alep et sa province à l'époque ottomane. Leiden: Brill 2019. 28-61.

437 SONG J, Denver's Chinatown 1875-1900: gone but not forgotten. Leiden: Brill 2019. pp x +203 .

438 SUDDLER C, Presumed criminal: black youth and the justice system in postwar New York. New York: New York University Press 2019. pp 256.

439 TAYLOR A, 'We have never employed Jewish people': young Jewish women's experiences of education and employment in Glasgow from the 1920s to the 1950s. CulSH 164 (2019) 467-89.

440 VON FRIJTAG DRABBE KÜNZEL G, Being and belonging: Benno Premsela, Joop Voet, Sándor Baracs and the Holocaust in Nazi-occupied Amsterdam. JGR 213 (2019) 418-35.

441 WEATHERSBY C \& WEATHERSBY Y, Branch school buildings in the St. Louis public schools district: tools to support the segregative neighborhood school policy of the St. Louis Board of Education. JUH 453 (2019) 483-99.

442 WEATHERSBY C \& WEATHERSBY Y, The 'intact busing' program in 1960s St. Louis public school district. JUH 455 (2019) 908-24.

443 WHIDDEN J, The Levantine British: defying imperial race categories in colonial Alexandria. BatW 121 (2019) 51-66.

444 WILLIAMS C, Labor radicalism and the local politics of Chinese exclusion: Mayor Jacob Weisbach and the Tacoma Chinese expulsion of 1885. LabH 606 (2019) 685-703.

445 YEMM R, Immigration, race and local media: Smethwick and the 1964 general election. CBH 331 (2019) 98-122.

446 ZACHS F, Children in war time: the first pupils of the Syrian (Schneller) orphanage in Jerusalem 1860-1863. MES 556 (2019) 958-73.

\section{Family life}

447 ARMSTRONG-PARTIDA M, Concubinage, illegitimacy and fatherhood: urban masculinity in latemedieval Barcelona. G \& H 311 (2019) 195-219.

448 DELMEDICO S, 'I forgive my sons for any disgust they might have caused me': Alvise I Mocenigo and the decline of paternal authority in nineteenth-century Venice. JFH 444 (2019) 347-65.

449 HARTON M-E, RICHARD L, MARCOUX R \& ST-HILAIRE M, Social space and family reproduction among Quebec City leather workers in 1911. ADH 2138 (2019) 55-82.

450 MICHALEAS S N \& SERGENTANIS T N, Dowries in Greece: dowry contracts in Ioannina during the early twentieth century. HF 244 (2019) 675-706.

451 RAGGAM-BLESCH M, 'Privileged' under Nazi-rule: the fat of three intermarried families in Vienna. JGR 213 (2019) 378-97.

452 SEILER S, Social homogamy, early industrialization, and marriage restrictions in the canton of Lucerne, Switzerland, 1834-75. HF 241 (2019) 38-66.

453 VAN LEEUWEN M H D, MAAS I, HIN S \& MATTHIJS K, Socio-economic modernization and enduring language barriers: choosing a marriage partner in Flemish communities, 1821-1913. HF 241 (2019) 94-122.

\section{Gender}

454 ABRAMS L, FLEMING L, HAZLEY B, WRIGHT V \& KEARNS A, Isolated and dependent: women and children in high-rise social housing in post-war Glasgow. WomHR 295 (2019) 794-813. 
455 ASTON J, CAPERN A \& MCDONAGH B, More than bricks and mortar: female property ownership as economic strategy in mid-nineteenth-century urban England. UH 464 (2019) 695-721.

456 AULD D, IRELAND T \& BURKE H, Affective aprons: object biographies from the Ladies' Cottage, Royal Derwent Hospital New Norfolk, Tasmania. IJHA 232 (2019) 361-79.

457 BALSOY G, Haseki Women's Hospital and the female destitute of nineteenth-century Istanbul. MES 553 (2019) 289-300.

458 BERNARDI T \& POMPERMAIER M, Hospitality and registration of foreigners in early modern Venice: the role of women within inns and lodging houses. $G$ \& $H 313$ (2019) 624-45.

459 BERNEY J, One woman's campaign: Stella Benson and the regulation of prostitution in 1930s colonial Hong Kong. WomHR 296 (2019) 933-49.

460 BEYINLI G, At liberty under occupation but bound hand and foot in the republic: Istanbul women, corruption and moral decay after the First World War (1918-1923). IJRLH 142 (2019) 94-109.

461 CHAKRAVARTY I, Owners, creditors and traders: women in late colonial Calcutta. IESHR 564 (2019) 427-56.

462 CHALUS E, Spaces of sociability in fashionable society: Brighton and Nice, c. 1825-35. In CHALUS E \& KAARTINEN M eds, Gendering spaces in European towns, 1500-1914. Abingdon: Routledge 2019. 75-95.

463 CHALUS E \& KAATINEN M, Conceived, constructed, and contested spaces: gender and European towns - introduction. In CHALUS E \& KAARTINEN M eds, Gendering spaces in European towns, 1500-1914. Abingdon: Routledge 2019. 1-11.

464 COLLINGE P, Guilds, authority and the individual: the Company of Mercers prosecution of Dorothy Gretton in early eighteenth-century Derby. BuH 612 (2019) 281-98.

465 DARLING E, An urban experiment in spiritual motherhood: gender, class and reform in Edwardian Edinburgh. In DARLING E \& WALKER N R eds, Suffragette city: women, politics, and the built environment. Abingdon: Routledge 2019. 7-31.

466 DATTA A B, 'Useful' and 'earning' citizens? Gender, state, and the market in post-colonial Delhi. MAsS 536 (2019) 1924-55.

467 DECKER S I, Between two cities: Jewish women and exogamous marriage in medieval Catalonia. JMH 454 (2019) 481-503.

468 DUNCAN S, Personating the Ripper: civilian performance and the melodramatic mode. NCTF 462 (2019) 190-209.

469 FISCHER A G, 'The place is gone!': policing black women to redevelop downtown Boston. JSocH 531 (2019) 7-26.

470 FISHER R, Gender, class and school teacher education from the mid-nineteenth century to 1970: scenes from a town in the North of England. HE 486 (2019) 806-18.

471 HARRISON L, 'The streets have been watched regularly': the York Penitentiary Society, young working-class women, and the regulation of behaviour in the public spaces of York, c. 1845-1919. WomHR 293 (2019) 457-78.

472 HENRY W, Hester Hammerton and women sextons in eighteenth- and nineteenth-century England. $G$ \& $H 312$ (2019) 404-21.

473 HOLLY N, 'The Indian woman Peggy': mobility, marriage, and power in an early American city. EMW 141 (2019) 85-94.

474 ILMAKUNNAS J, Aristocratic townhouse as urban space: the Fersen Palace in eighteenth-century Stockholm. In CHALUS E \& KAARTINEN M eds, Gendering spaces in European towns, 15001914. Abingdon: Routledge 2019. 12-29.

475 JACKSON A, Gender, photography and women's football in England: the Portsmouth Ladies FC, 1916-1918. SpiH 394 (2019) 376-94.

476 JENKIN A, Wives with knives and lovers: murder and marital households in eighteenth-century London and Paris. In CHALUS E \& KAARTINEN M eds, Gendering spaces in European towns, 1500-1914. Abingdon: Routledge 2019. 204-20.

477 KAARTINEN M, 'A busy day with me, or at least with my feet and my stockings': walking for health and the female pedestrian's spaces in eighteenth-century British towns. In CHALUS E \& KAARTINEN M eds, Gendering spaces in European towns, 1500-1914. Abingdon: Routledge 2019. $30-44$. 
478 KEATING A D, The world of Juliette Kinzie: Chicago before the fire. Chicago: University of Chicago Press 2019. pp 272.

479 KING C, The special value of precarious patrons: Lucrezia Agliardi and the tradition of Italian laywomen church builders. EMW 132 (2019) 33-57.

480 LAM N L, Women as pleasure seekers: courtesans, actresses, and female visitors in the amusement halls of early republican Shanghai. JUH 454 (2019) 671-92.

481 LANGEN U, Pride and resentment: French émigrés and republicans in the streets of late eighteenthcentury Copenhagen. In CHALUS E \& KAARTINEN M eds, Gendering spaces in European towns, 1500-1914. Abingdon: Routledge 2019. 221-37.

482 LEONARD V, Galla Placidia as 'human gold': consent and autonomy in the Sack of Rome, CE 410. G \& H 312 (2019) 334-52.

483 LONG B, The needle not the spindle? Domestic training at the London Asylum or House of Refuge for Orphan and Deserted Girls in the eighteenth century. LJ 441 (2019) 37-53.

484 MCGOWAN L, Women's association football (soccer) in Brisbane, Queensland 1921-1933: new perspectives on early competition. SpiH 392 (2019) 187-206.

485 MANDELL N, A hotel of her own: building by and for the new woman, 1900-1930. JUH 453 (2019) $517-41$.

486 MASON R, Women, marital status, and law: the martial spectrum in seventeenth-century Glasgow. JBS 584 (2019) 787-804.

487 MAZANIK A, The city of men: gender, space and working-class domesticity in late-imperial Moscow. In CHALUS E \& KAARTINEN M eds, Gendering spaces in European towns, 1500-1914. Abingdon: Routledge 2019. 116-34.

488 MONTENACH A, 'Uncontrolled crossings': gender and illicit economic territories in eighteenthcentury French towns. In CHALUS E \& KAARTINEN M eds, Gendering spaces in European towns, 1500-1914. Abingdon: Routledge 2019. 135-53.

489 NEUMAN J, Gilded suffragettes: the New York socialites who fought for women's right to vote. New York: New York University Press 2019. pp 240.

490 PALM R, The mother's house of the San Francisco Zoo: the art of engendering space in the modern city. WomHR 293 (2019) 437-56.

491 PHIPPS T, Coverture and the marital partnership in late medieval Nottingham: women's litigation at the borough court, ca. 1300-ca. 1500. JBS 584 (2019) 768-86.

492 PHIPPS T, Female litigants and the borough court: status and strategy in the case of Agnes Halum of Nottingham. In GODDARD R \& PHIPPS T eds, Town courts and urban society in late medieval England, 1250-1500. Woodbridge: Boydell \& Brewer 2019. 77-92.

493 PIERICK B \& GEELEN A, A tale of two Johannas: gatekeeping, mobilities, and marriage in Cochin and Amsterdam. EMW 141 (2019) 131-40.

494 PROCTER III F T, 'Alien to my sex': enslaved women and their gendered notions of abuse in eighteenth-century Lima, Peru. JWomH 312 (2019) 57-79.

495 RAHIKAINEN M, Marriage markets for elite women: imperial St Petersburg and Helsinki. In CHALUS E \& KAARTINEN M eds, Gendering spaces in European towns, 1500-1914. Abingdon: Routledge 2019. 96-115.

496 RECOBA M V, Women writers and Hispanic hegemony in the 17th-century viceroyalty of Peru: the cases of Clarinda and Amarilis. In ENGEL E A ed, A companion to early modern Lima. Leiden: Brill 2019. 235-52.

497 SACHS M, 'But the child is flighty, playful, curious': working-class boyhood and the policing of play in Belle Époque Paris. HR/RH 452 (2019) 7-27.

498 SANTANGELO L C, Suffrage and the city: New York women battle for the ballot. Oxford: Oxford University Press 2019. pp 264.

499 SCHJERNING C, Behind thin walls: contested spaces and spheres of authority in late eighteenthcentury Copenhagen. In CHALUS E \& KAARTINEN M eds, Gendering spaces in European towns, 1500-1914. Abingdon: Routledge 2019. 187-203.

500 SENNEFELT K, Absent men and tainted houses: gender, place and self in Stockholm in 1719. In CHALUS E \& KAARTINEN M eds, Gendering spaces in European towns, 1500-1914. Abingdon: Routledge 2019. 170-86. 
501 SIMONTON D, 'For the gentlemen for the town to walk on by way of exchange': gender, space and commerce in the eighteenth-century town. In CHALUS E \& KAARTINEN M eds, Gendering spaces in European towns, 1500-1914. Abingdon: Routledge 2019. 45-74.

502 STRIDE R, Women, work and deindustrialisation: the case of James Templeton \& Company, Glasgow, c. 1960-1981. SLH 541 (2019) 154-80.

503 TAVERNER C, Consider the oyster seller: street hawkers and gendered stereotypes in early modern London. HWJ 881 (2019) 1-23.

504 TEUBNER M, Street food, urban space, and gender: working on the streets of nineteenth-century Rio de Janeiro (1830-1870). IRSH 64 S27 (2019) 229-54.

505 TILBURG P, Working girls: sex, taste, and reform in the Parisian garment trades, 1880-1919. Oxford: Oxford University Press 2019. pp 288.

506 VAN DEN HEUVEL D, Gender in the streets of the premodern city. JUH 454 (2019) 693-710.

507 VERBRUGGEN T, The arrival of foreign female domestic servants in Antwerp and the role of compatriots and relatives as intermediaries, 1860-1880. G \& H 313 (2019) 584-604.

508 WALKER N R, Life and breath to the city: women, urbanism, and the birth of the historic preservation movement. In DARLING E \& WALKER N R eds, Suffragette city: women, politics, and the built environment. Abingdon: Routledge 2019. 57-85.

509 WEDDLE S, Mobility and prostitution in early modern Venice. EMW 141 (2019) 95-108.

510 ZIPF C W, Almost as good as a Frank Gehry: Doris Duke, Maya Lin, and the gendered politics of public space in Newport, Rhode Island. In DARLING E \& WALKER N R eds, Suffragette city: women, politics, and the built environment. Abingdon: Routledge 2019. 161-81.

\section{Sexualities}

511 ANDERSSON J, Homonormative aesthetics: AIDS and 'de-generational unremembering' in 1990s London. US 5614 (2019) 2993-3010.

512 CASLIN S, Transience, class and gender in interwar sexual health policy: the case of the Liverpool VD scheme. SHMed 313 (2019) 544-64.

513 COLLIGAN C, Digital discovery and fake imprints: unmasking turn-of-the-century pornographers in Paris. BookH 221 (2019) 249-79.

514 COOK M, Local turns: queer histories and Brighton's queer communities. HC 1710 (2019) 1-12.

515 ELLISON T, From sanctuary to safe space: gay and lesbian police-reform activism in Los Angeles. RHR 1353 (2019) 95-118.

516 ZIEMAN K, Minding the rod: sodomy and clerical masculinity in fifteenth-century Leicester. $G \& H$ 311 (2019) 60-77.

\section{Economic activity}

\section{Urban economic activity}

517 ADE M, L'innovation judiciaire dans l'Empire ottoman : l'établissement d'un tribunal de commerce à Alep au milieu du xixe siècle. In WINTER S \& ADE M eds, Aleppo and its hinterland in the Ottoman period/Alep et sa province à l'époque ottomane. Leiden: Brill 2019. 175-203.

518 AGO R, Rome's economic life, 1492-1692. In JONES P M, WISCH B \& DITCHFIELD S eds, A companion to early modern Rome, 1492-1692. Leiden: Brill 2019. 184-98.

519 ALFANI G \& PERCOCO M, Plague and long-term development: the lasting effects of the 1629-30 epidemic on the Italian cities. EcHR 724 (2019) 1175-201.

520 APPELGREN S, History as business: changing dynamics of retailing in Gothenburg's second-hand market. BuH 611 (2019) 172-86.

521 BECKWITH I, William Briggs of Great Yarmouth 1799-1864: cabin boy to ship owner. LocH 491 (2019) 13-15.

522 BRUNNBAUER U \& HODGES A, The long hand of workers' ownership: performing transformation in the Uljanik Shipyard in Yugoslavia/Croatia, 1970-2018. IJMH 314 (2019) 860-78. 
523 BUKOWSKI M, KORYŚ P, LESZCZYŃSKA C, TYMIŃSKI M \& WOLF N, Urbanization and GDP per capita: new data and results for the Polish lands, 1790-1910. HM 524 (2019) 213-27.

524 BUNNELL T, Liverpool in the relational remaking of Singapore: global city routes and Malay seafaring mobilities. In WEBSTER A \& WHITE N J eds, Singapore - two hundred years of the Lion City. Abingdon: Routledge 2019. 156-73.

525 BUSCH, M, Coventry at war: industrial relations, ownership and production. In BEGLEY J, DONNELLY T, JARVIS D \& SISSONS P eds, Revival of a city: Coventry in a globalising world. London: Palgrave Macmillan 2019. 41-65.

526 CASSON C \& CASSON M, Property rents in medieval English towns: Hull in the fourteenth century. UH 463 (2019) 347-97.

527 COLLIS C, Recession and relative recovery. In BEGLEY J, DONNELLY T, JARVIS D \& SISSONS P eds, Revival of a city: Coventry in a globalising world. London: Palgrave Macmillan 2019. 93-123.

528 CRISTINA G, Persistence and evolution in the eastern Sicilian coastal corridor: the mobility of goods and people at the post of Catania (1817-1860). In FAVERO G, SERRUYS M-W \& SUGIURA M eds, The urban logistic network. London: Palgrave Macmillan 2019. 101-21.

529 DREIJER G, The afterlife of the Ostend Company, 1727-1745. MM 1053 (2019) 275-87.

530 FAVERO G, Gateways as inter-modal nodes in different ages: the Venetian region, eighteenth to twentieth centuries. In FAVERO G, SERRUYS M-W \& SUGIURA M eds, The urban logistic network. London: Palgrave Macmillan 2019. 173-90.

531 FLOWER B C R, Legal geographies of neoliberalism: market-orientated tenure reforms and the construction of an 'informal' urban class in post-socialist Phnom Penh. US 5611 (2019) 2408-25.

532 GODDARD R, Trust: business networks and the borough court. In GODDARD R \& PHIPPS T eds, Town courts and urban society in late medieval England, 1250-1500. Woodbridge: Boydell \& Brewer 2019. 176-99.

533 GRAUBART K B, Taxation, obligation, and corporate identity in 16th-century Lima. In ENGEL E A ed, A companion to early modern Lima. Leiden: Brill 2019. 82-102.

534 GREEN D R, Tontines, annuities and civic improvements in Georgian Britain. UH 464 (2019) 649-94.

535 HAGGERTY S, What's in a price? The American raw cotton market in Liverpool and the Anglo-American War. BuH 616 (2019) 942-70.

536 HALLÉN P, Gateway of Gothenburg. In FAVERO G, SERRUYS M-W \& SUGIURA M eds, The urban logistic network: cities, transport and distribution in Europe from the Middle Ages to modern times. London: Palgrave Macmillan 2019. 23-49.

537 HAYNES M, Coventry in the long boom 1950-1970. In BEGLEY J, DONNELLY T, JARVIS D \& SISSONS P eds, Revival of a city: Coventry in a globalising world. London: Palgrave Macmillan 2019. 67-92.

538 HESSION P, Wholesome regulation and unlimited freedom': governing market space in southern Ireland before the Famine. UH 461 (2019) 21-43.

539 HUANG A L, Lübeck's trade in the fifteenth century. In JAHNKE C ed, A companion to medieval Lübeck. Leiden: Brill 2019. 253-72.

540 JAHNKE C, Lübeck: early economic development and the urban hinterland. In JAHNKE C ed, $A$ companion to medieval Lübeck. Leiden: Brill 2019. 226-52.

541 KOBAYASHI A, The origins of Singapore's economic prosperity, c. 1800-1874. In WEBSTER A \& WHITE N J eds, Singapore - two hundred years of the Lion City. Abingdon: Routledge 2019. 11-28.

542 MACICA K, Fortress city: the militarized landscape of Seattle. In LAAKKONEN S, MCNEILL J R, TUCKER R P \& VUORISALO T eds, The resilient city in World War II: urban environmental histories. London: Palgrave Macmillan 2019. 47-67.

543 MACKIE M, The rebirth of the phoenix city - sectorial shifts and the evolution of Coventry's economic base. In BEGLEY J, DONNELLY T, JARVIS D \& SISSONS P eds, Revival of a city: Coventry in a globalising world. London: Palgrave Macmillan 2019. 199-227.

544 MARTIRE A, Bridging the gap: the Belfast-Dublin railway corridor in the nineteenth century. In FAVERO G, SERRUYS M-W \& SUGIURA M eds, The urban logistic network: cities, transport and distribution in Europe from the Middle Ages to modern times. London: Palgrave Macmillan 2019. 123-42. 
545 MOCARELLI L, The construction of an inland gateway: Milan in the course of the early modern period. In FAVERO G, SERRUYS M-W \& SUGIURA M eds, The urban logistic network: cities, transport and distribution in Europe from the Middle Ages to modern times. London: Palgrave Macmillan 2019. 161-71.

546 MOMDJIAN M, Halabis and foreigners in Aleppo's Mediterranean trade: the role of Levantine merchants in eighteenth-century commercial networks. In WINTER S \& ADE M eds, Aleppo and its hinterland in the Ottoman period/Alep et sa province à l'époque ottomane. Leiden: Brill 2019. 109-29.

547 MORELLI S, Tax evasion in cities of the kingdom of Naples under the Angevin monarchy. HU 541 (2019) 121-37.

548 NAISMITH R, The laws of London? IV Æthelred in context. LJ 441 (2019) 1-16.

549 NEWSON L A, Piety, beeswax and the Portuguese African slave trade to Lima, Peru, in the early colonial period. AtlSt 162 (2019) 144-62.

550 NORRIS L, Urban prototypes: growing local circular cloth economies. BuH 611 (2019) 205-24.

551 ODEGARD E, Construction at Cochin: building ships at the VOC-yard in Cochin. IJMH 313 (2019) 481-94.

552 PETERSON E D, The Urban Development Corporation's 'imaginative use of credit': creating capital for affordable housing development. JUH 456 (2019) 1174-92.

553 RUOSS M, Fighting unfair competition: the Bamberger Riot and the emergence of hire purchase in Switzerland around 1900. JSocH 531 (2019) 194-217.

554 SCHELTJENS W, Ports and their functions: some reflections about preindustrial logistics. In FAVERO G, SERRUYS M-W \& SUGIURA M eds, The urban logistic network: cities, transport and distribution in Europe from the Middle Ages to modern times. London: Palgrave Macmillan 2019. 209-23.

555 SERRUYS M-W, Urban networks on the move: the Austrian Netherlands' transit policy and the development of the Belgian urban networks in the eighteenth century (1704-1793). In FAVERO G, SERRUYS M-W \& SUGIURA M eds, The urban logistic network. London: Palgrave Macmillan 2019. 75-100.

556 STEPEHNSON J Z, The economic institutions of construction in London after the Great Fire. ES 201 (2019) 229-52.

557 SUÁREZ M, Lima and the introduction of Peru into the global trade of the 16th century. In ENGEL E A ed, A companion to early modern Lima. Leiden: Brill 2019. 171-95.

558 SUGIURA M, Tracking waters: small cities transport network of early modern Friesland. In FAVERO G, SERRUYS M-W \& SUGIURA M eds, The urban logistic network: cities, transport and distribution in Europe from the Middle Ages to modern times. London: Palgrave Macmillan 2019. 225-48.

559 TONELLI G, Urban network and economic policy: the Milanese case during the Spanish and Austrian ages. In FAVERO G, SERRUYS M-W \& SUGIURA M eds, The urban logistic network: cities, transport and distribution in Europe from the Middle Ages to modern times. London: Palgrave Macmillan 2019. 145-60.

560 VANAIK A, Possessing the city: property and politics in Delhi, 1911-1947. Oxford: Oxford University Press 2019. pp 272.

561 WHITE N J, The economics of Singapore's exit from Malaysia. In WEBSTER A \& WHITE N J eds, Singapore - two hundred years of the Lion City. Abingdon: Routledge 2019. 99-120.

\section{Industry}

562 BEGLEY J, Occupational structure and change in post-war Coventry. In BEGLEY J, DONNELLY T, JARVIS D \& SISSONS P eds, Revival of a city: Coventry in a globalising world. London: Palgrave Macmillan 2019. 165-97.

563 CAREY C, STREMKE F \& HUMPHRIS J, The ironworking remains in the royal city of Meroe: new insights on the Nile Corridor and the Kingdom of Kush. A 93368 (2019) 432-49.

564 PELTOLA J, The British contribution to the birth of the Finnish cotton industry (1820-1870). ContC 341 (2019) 63-89. 


\section{External trade}

565 POURCHASSE P, The flaxseed trade between Courland and Brittany in the eighteenth century. In FAVERO G, SERRUYS M-W \& SUGIURA M eds, The urban logistic network: cities, transport and distribution in Europe from the Middle Ages to modern times. London: Palgrave Macmillan 2019. 193-207.

\section{Food supply}

566 ALBRECHT J M, The struggle for bread. The emperor, the city and the bakers between moral and market economics of food in Vienna, 1775-1791. HRC 53 (2019) 276-94.

567 GUNN G C, Japanese-occupied Hanoi: war, famine, and famine management in the Red River delta. In LAAKKONEN S, MCNEILL J R, TUCKER R P \& VUORISALO T eds, The resilient city in World War II: urban environmental histories. London: Palgrave Macmillan 2019. 219-36.

568 GUTZKE D W, John Pearce and the rise of the mass food market in London, 1870-1930. London: Palgrave Macmillan 2019. pp xv +257.

569 KING S C, Sinophile consumption: Chinese restaurants and consumer culture in turn-of-the-century American cities. GFH 53 (2019) 162-82.

570 LAFFIN S, Occupied Naples and the politics of food in World War II. In KEOGH T ed, War and the city: the urban context of conflict and mass destruction. Leiden: Brill 2019. 139-66.

571 LUDINGTON C C, Inventing Grand Cru Claret: Irish wine merchants in eighteenth-century Bordeaux. GFH 5 1-2 (2019) 25-44.

572 OGÓREK B, Feeding the city, feeding the fortress: Cracow's food supply in World War I. JUH 454 (2019) 747-64.

573 SPRENGER-SEYFFARTH J, Public feeding in the First World War: Berlin's first public kitchen system. In BENBOW H M \& PERRY H R eds, Culture and identity in Germany's century of war. London: Palgrave Macmillan 2019. 75-102.

574 TANGIRES H, Movable markets: food wholesaling in the twentieth-century city. Baltimore, MD: Johns Hopkins University Press 2019. pp 312.

575 VIANA V \& KIM K Y, Rice scarcity in World War II Macao: the local experience revisited. UH 463 (2019) 518-41.

\section{Finance, banking and industry}

576 FJESME S, GALPIN N \& MOORE L, An efficient market? Going public in London, 1891-1911. EcHR 723 (2019) 1008-27.

577 GALLAIS-HAMONNO G, HOANG T-H-V \& OOSTERLINCK K, Price formation on clandestine markets: the case of the Paris gold market during the Second World War. EcHR 723 (2019) 1048-72.

578 HOWELL M, Credit networks and political actors in thirteenth-century Ypres. $P$ \& $P 2421$ (2019) 336.

579 KAWAMURA T, Trade, finance, and the 'Anglo-Dutch' international order in Southeast Asia: the case of the British eastern exchange banks, 1870-1890. In WEBSTER A \& WHITE N J eds, Singapore - two hundred years of the Lion City. Abingdon: Routledge 2019. 46-61.

580 KNIGHT G R, Made in Singapore: 'good steady scotsmen', the Lion City and London, 1820s-1870s. In WEBSTER A \& WHITE N J eds, Singapore - two hundred years of the Lion City. Abingdon: Routledge 2019. 29-45.

581 KOBAYASHI A, International bimetallism and silver absorption in Singapore, 1840-73. EcHR 722 (2019) 595-617.

582 KUEHN T, Lorenzo de' Medici and inheritance law in Florence. RS 342 (2019) 243-59.

583 VILLE S \& WRIGHT C, Buzz and pipelines: knowledge and decision-making in a global business services precinct. JUH 452 (2019) 191-210.

584 WARD J, Financing the information age: London TeleCity, the legacy of IT-82, and the selling of British Telecom. TCBH 303 (2019) 424-46. 


\section{Consumption}

585 AMICHAY O, BEN-AMI D, TCHEKHANOVETS Y, SHAHACK-GROSS R, FUKS D \& WEISS E, A bazaar assemblage: reconstructing consumption production and trade from mineralised seeds in Abbasid Jerusalem. A 93367 (2019) 199-217.

586 THOMAS K L, This strange interloper: building products and the emergence of the architectshopper in 1930s Britain. In DARLING E \& WALKER N R eds, Suffragette city: women, politics, and the built environment. Abingdon: Routledge 2019. 112-38.

587 WARNABY G, The Victorian arcade as a contemporary retail form? HRC 52 (2019) 150-68.

\section{Earnings}

588 KRENZKE J R, Resistance by the pint: how London brewers shaped the excise and created London's favorite beer. JEMH 236 (2019) 499-518.

\section{Standard of living}

589 CAVIN A, A right to housing in the suburbs: James $v$. Valtierra and the campaign against economic discrimination. JUH 453 (2019) 427-51.

590 CHHABRIA S, Citing the poor: commercial sovereignty and capitalist integration in colonial Karachi. JUH 455 (2019) 987-1005.

\section{Working conditions}

591 ALBERTO P L, Liberta by trade: negotiating the terms of unfree labor in gradual abolition Buenos Aires (1820s-30s). JSocH 523 (2019) 619-51.

592 CHATTERJEE S, The labors of failure: labor, toxicity, and belonging in Mumbai. ILWCH 951 (2019) 49-75.

593 DOHERTY J, Capitalizing community: waste, wealth, and (im)material labor in Kampala. ILWCH 95 1 (2019) 95-113.

594 JENNINGS E P, The path to sweet success: free and unfree labor in the building of roads and rails in Havana, Cuba, 1790-1835. IRSH 64 S27 (2019) 149-71.

595 KATSUHIKO S, Suppliers of labour in the pre-war port of Ōsaka. HU 552 (2019) 13-34.

596 PARIKH A, Inroads for the outsourced: call-center graveyard shifts and women's impact on the nocturnal streets of Mumbai, India. In DARLING E \& WALKER N R eds, Suffragette city: women, politics, and the built environment. Abingdon: Routledge 2019. 202-20.

597 STRANGLEMAN T, Voices of Guinness: an oral history of the Park Royal Brewery. Oxford: Oxford University Press 2019. pp 240.

598 TERRY-CHANDLER F E, Compulsory industriousness: working conditions and exploitation in Birmingham during the Industrial Revolution. MidH 441 (2019) 71-84.

599 THOMAS M C, Securing trade: the military labor of the British occupation of Manila, 1762-1764. IRSH 64 S27 (2019) 125-47.

\section{Labour organization}

600 BRANDON P, FRYKMAN N \& RøGE P, Free and unfree labor in Atlantic and Indian Ocean port cities. IRSH 64 S27 (2019) 1-18.

601 CAIN E, 'We used to be patrons - now we are pickets!': the League of Women Shoppers, the picket line, and identity formation, 1935-1949. JWomH 313 (2019) 35-56.

602 CHAKRABORTY T, The household workers of the East India Company ports of pre-colonial Bengal. IRSH 64 S27 (2019) 71-93.

603 COGSWELL T, Ten demi-culverins for Aldeburgh: Whitehall, the Dunkirkers, and a Suffolk fishing community, 1625-1630. JBS 582 (2019) 315-37.

604 ESBENSHADE J, SHIFRIN E \& RIDER K, Leveraging liminality: how San Diego taxi drivers used their precarious status to win reform. $\mathrm{LabH}$ (2019) 79-95.

605 FENDER S, The global perspective of urban labor in Mexico City, 1910-1929: el mundo al réves. Abingdon: Routledge 2019. pp 216.

606 GASSE I, The Dumfries bakers' strike of 1905. SLH 541 (2019) 79-102. 
607 JEAN M, Liberated Africans, slaves, and convict labor in the construction of Rio de Janeiro's Casa de Correção: Atlantic labor regimes and confinement in Brazil's port city. IRSH 64 S27 (2019) 173-204.

608 MCKINLAY A, BOYLE J \& KNOX W, 'A sort of fear-run place': unionising better sound recordings, East Kilbride, 1969. SLH 541 (2019) 103-25.

609 MINCHIN T J, Look at Detroit: the United Auto Workers and the battle to organize Volkswagen in Cattanooga. LabH 605 (2019) 482-502.

610 REDIKER M, Afterword: reflections on the motley crew as port city proletariat. IRSH 64 S27 (2019) 255-62.

611 RIBEIRO A, 'We want both!': pressuring Philadelphia unions for inclusion and equity during the long 1970s. LabH 605 (2019) 558-70.

612 VAN ROSSUM M, Labouring transformations of amphibious monsters: exploring early modern globalization, diversity, and shifting clusters of labour relations in the context of the Dutch East India Company (1600-1800). IRSH 64 S27 (2019) 19-42.

613 YONEYAMA M, The decline of guilds and their monopoly in English provincial towns, with particular reference to Exeter. UH 463 (2019) 443-63.

\section{Communications}

\section{Inter-urban communications}

614 DAVIDS K, Cities, long distance corporations and open air sciences: Antwerp, Amsterdam and Leiden in the early modern period. In DE MUNCK B \& ROMANO A eds, Knowledge and the early modern city: a history of entanglements. Abingdon: Routledge 2019. 130-53.

615 GILDING B, The rise and fall of Hicky's Bengal Gazette (1780-2): a study in transoceanic political culture. JICH 471 (2019) 1-27.

616 HUWS G, 'The ceaseless labour of your life': occupations and wages in Holyhead, 1841-81. WHR 29 4 (2019) 562-93.

617 KEENAN C R, English news in papal Rome: cross-confessional information exchange in Reformation Europe. JEMH 234 (2019) 350-66.

618 LESSOFF A, James Bryce, William T. Stead, and the trans-Atlantic meaning of the American city. IJRLH 142 (2019) 76-93.

619 LOH K S, Experts in the making of Singapore. In WEBSTER A \& WHITE N J eds, Singapore - two hundred years of the Lion City. Abingdon: Routledge 2019. 174-90.

620 ROSE J, Between Boston and Bombay: cultural and commercial encounters of Yankees and Parsis, 1771-1865. London: Palgrave Macmillan 2019. pp xx +328.

\section{Intra-urban communications}

621 ANDERSON D N, 'Reconstructing the Jehus': how the telegraph tamed 'the hack nuisance' in San Francisco. JUH 452 (2019) 265-78.

622 MEER M, Reversed, defaced, replaced: late medieval London and the heraldic communication of discontent and protest. JMH 455 (2019) 618-45.

623 MÜLLER L, Sweden's early-modern neutrality: neutral vessels, prize cases and diplomatic actors in London in the late eighteenth century. JEMH 235 (2019) 475-90.

\section{Politics and administration \\ Aspects of urban administration}

624 ATASHROO H A, Weaponising peace: the Greater London Council cultural policy and 'GLC peace year 1983'. CBH 332 (2019) 170-86. 
625 AUBIN K, En quête de financement pour la création d'une clinique externe et d'un service social comme parachèvement de la désinstitutionnalisation à l'Hôpital Saint-Michel-Archange de Beauport, 1961-72. CBMH 362 (2019) 281-307.

626 BARNES N E, Partial resilience in nationalist China's wartime capital: surviving in Chongqing. In LAAKKONEN S, MCNEILL J R, TUCKER R P \& VUORISALO T eds, The resilient city in World War II: urban environmental histories. London: Palgrave Macmillan 2019. 203-18.

627 BLOOM N D, How states shaped postwar America: state government and urban power. Chicago: University of Chicago Press 2019. pp 392.

628 CHICK J, Urban oligarchy and dissolutioned voters: the end of monastic rule in Reading, 1350-1600. CulsH 164 (2019) 387-411.

629 CHOWKWANYUN M, Rethinking private-public partnership in the health care sector: the case of municipal hospital affiliation. BHM 934 (2019) 483-517.

630 COUPERUS S \& VRHOCI D, A profitable friendship, still? Town twinning between Eastern and Western European cities before and after 1989. In BRAAT E \& CORDUWENER P eds, 1989 and the West: Western Europe since the end of the Cold War. London: Routledge 2019. 128-42.

631 CUENCA E L, Town clerks and the authorship of custumals in medieval England. UH 462 (2019) 180-201.

632 DAVIES A, Police violence and judicial bias in the age of mass democracy: Glasgow, 1933-1935. SH 441 (2019) 57-85.

633 DYER C, Courts and urbanisation: jurisdiction in late medieval seigneurial boroughs and towns. In GODDARD R \& PHIPPS T eds, Town courts and urban society in late medieval England, 1250-1500. Woodbridge: Boydell \& Brewer 2019. 93-116.

634 FAYRER-JONES E J, 'Make him an offer he can't refuse': corruption, coercion and aristocratic landowners in nineteenth-century, urban Wales. IJRLH 142 (2019) 62-75.

635 GHOSH U, Combating 'filth': the temple, the state, and urbanization in late nineteenth-century Puri. MAsS 536 (2019) 1849-91.

636 GILBERT A, Corruption in urban Latin America: the case of Bogotá. IJRLH 142 (2019) 126-41.

637 HARTRICH E, Politics and the urban sector in fifteenth-century England, 1413-1471. Oxford: Oxford University Press 2019. pp 288.

638 HOME R, From cantonments to townships: Lugard's influence upon British colonial urban governance in Africa. PLP 341 (2019) 43-64.

639 HOSTETTER E, The landscapes of early automobile registration and licensing laws: creating New Jersey's Department of Motor Vehicles, 1903 to 1957. JUH 453 (2019) 452-82.

640 LAFI N, Espirit civique et organisation citadine dans l'Empire ottoman (XVe-XXe siècles). Leiden: Brill 2019. pp xii +360 .

641 LAUGHTON J, Justice and jurisdictions in late medieval Chester. In GODDARD R \& PHIPPS T eds, Town courts and urban society in late medieval England, 1250-1500. Woodbridge: Boydell \& Brewer 2019. 156-75.

642 MANTENA R S, Publicity, civil liberties, and political life in princely Hyderabad. MAsS 534 (2019) 1248-77.

643 MARET A, The port of Marseille in the 16th century: the crucible for the links between municipal authorities and the sovereign. HU 563 (2019) 153-76.

644 MERTON J, John Lindsay, the Association for a Better New York, and the privatization of New York City, 1969-1973. JUH 453 (2019) 557-77.

645 MORRIS R J, Reading the riot commission: Belfast, 1857. HIS 43164 (2019) 194-219.

646 OSBORNE T, Diplomatic culture in early modern Rome. In JONES P M, WISCH B \& DITCHFIELD S eds, A companion to early modern Rome, 1492-1692. Leiden: Brill 2019. 60-74.

647 PARDO I, Embedding corruption into governance: the 'graveyard affair' in 1970s Naples and its aftermath. IJRLH 142 (2019) 110-25.

648 PEARS R, A council at war: Whickham Urban District Council 1939-45. NH 56 1-2 (2019) 117-37.

649 PEARSON C, Combating canine 'visiting cards': public hygiene and the management of dog mess in Paris since the 1920s. SHMed 311 (2019) 143-65.

650 RAWSON G, Poor relief administration in the 1840s, and its effect on the poor: the Carlton Gilbert Incorporation, and Holbeck, Leeds. NH 56 1-2 (2019) 78-96. 
651 SIMPSON J, House style: the politics, conventions and practices of house-naming in nineteenthcentury Cheltenham. LocH 492 (2019) 194-206.

652 STEWART T A W, By-elections and political change in a local context: the case of the 1873 Dundee East by-election and the SNP. ParlH 382 (2019) 262-77.

653 STOCKWELL A J, 'The Gibralter of the East'? Singapore and other fortress colonies during the Second World War. In WEBSTER A \& WHITE N J eds, Singapore - two hundred years of the Lion City. Abingdon: Routledge 2019. 191-206.

654 TARR J, Lighting the streets, alleys, and parks of the Smoky City, 1816-1930. PH 863 (2019) 315-34.

655 TEAFORD J C, The unheralded triumph: city government in America, 1870-1900. Baltimore, MD: Johns Hopkins University Press 2019. pp 386.

656 WARWICK T, Challenging the 'decline' of the industrial elite in the manufacturing town: Middlesbrough's steel magnates and the urban sphere 1880-1931. LocH 493 (2019) 230-8.

657 WEBSTER A, Singapore, the Straits Settlements and the politics of imperial commerce, 1819-1867. In WEBSTER A \& WHITE N J eds, Singapore - two hundred years of the Lion City. Abingdon: Routledge 2019. 121-39.

\section{Political activism}

658 ABOU-EL-FADL R, Building Egypt's Afro-Asian hub: infrastructure of solidarity and the 1957 Cairo Conference. JWH 30 1-2 (2019) 157-92.

659 ALEMÁN M G, Order of freedom? Redefining the public space of Buenos Aires in the 1930s. HU 55 2 (2019) 141-61.

660 ALEMÁN M G \& MORET F, Rethinking the political uses of the street, early 20th century EuropeAmericas-Asia. HU 552 (2019) 81-9.

661 BAILEY M, Changing tides of industrial democracy: Red Clydeside and the UCS work-in as political heritage. IJHerS 2512 (2019) 1319-38.

662 BALACHANDRAN A, Petitions, the city, and the early colonial state in South India. MAsS 531 (2019) 150-76.

663 BORYS A M, The 'minister of municipalities': shared space and social fabric in the work of Caroline Bartlett Crane. In DARLING E \& WALKER N R eds, Suffragette city: women, politics, and the built environment. Abingdon: Routledge 2019. 88-111.

664 BREITENBACH E, Edinburgh suffragists: exercising the franchise at local level. BOEC 151 (2019) 63-80.

665 BUCKELL J, The women's suffrage movement in Northamptonshire. LocH 492 (2019) 133-47.

666 CENSER J R, Prelude to power: the Parisian radical press, 1789-1791. Baltimore, MD: Johns Hopkins University Press 2019. pp 210.

667 COLLINS C \& LEVITT I, The policy discourses that shaped the 'transformation' of Glasgow in the later 20th century: 'overspill', 'redeployment' and the 'culture of enterprise'. In KINTREA K \& MADGIN R eds, Transforming Glasgow: beyond the post-industrial city. Bristol: Policy Press 2019. 21-38.

668 FAIRBURN H, The women's suffrage movement in Ripon, Northallerton and Harrogate. LocH 492 (2019) 148-54.

669 FEHR R M, Political Protestantism: the Detroit Citizens League and the rise of the Ku Klux Klan. JUH 456 (2019) 1153-73.

670 FORSTER L C, The Paris Commune in London and the spatial history of ideas, 1871-1900. HJ 624 (2019) 1021-44.

671 HINSHELWOOD J, Hotbeds of resistance in the First World War: conscientious objection in Birmingham and London. LocH 492 (2019) 121-32.

672 HOLTZMAN B, 'Shelter is only a first step': housing the homeless in 1980s New York City. JSocH 52 3 (2019) 886-910.

673 KAAL H \& KIRKELS C, Public order acts and their effects on street politics in 1930s Europe: a case study of Britain and the Netherlands. HU 552 (2019) 125-40.

674 KAICKER A, Petitions and local politics in the late Mughal empire: the view from Kol, 1741. MAsS 531 (2019) 21-51.

675 KIDAMBI P, The petition as event: colonial Bombay, circa 1889-1914. MAsS 531 (2019) 203-39. 
676 MCENEANEY S, Home sweet home? Housing activism and political commemoration in sixties Ireland. HWJ 871 (2019) 5-26.

677 MCNAMARA S, Borderland unionism: Latina activism in Ybor City and Tampa, Florida, 19351937. JAEH 384 (2019) 10-32.

678 MERWOOD-SALISBURY J, Design for the crowd: patriotism and protest in Union Square. Chicago: University of Chicago Press 2019. pp 312.

679 MOSS J, Women, workplace protest and political identity in England, 1968-85. Manchester: Manchester University Press 2019. pp 208.

680 PERRY E I, After the vote: feminist politics in La Guardia's New York. Oxford: Oxford University Press 2019. pp 384.

681 POOLE R, Peterloo: the English uprising. Oxford: Oxford University Press 2019. pp 480.

682 PROVENZANO L, Beyond the Matraque: state violence and its representation during the Parisian 1968 events. JModH 913 (2019) 586-624.

683 RAMAN B, Civil address and the early colonial petition in Madras. MAsS 531 (2019) 123-49.

684 REZVANI-NARAGHI A, A street-less revolution: the production of political public spaces during Iran's 1905-06 constitutional revolution. HU 552 (2019) 91-106.

685 RIBEIRO A, 'Asking them and protesting': black Puerto Rican civic leadership in Philadelphia neighborhoods, 1960s-1970s. PH 863 (2019) 359-82.

686 STEWART T A W, A disguised Liberal vote'? - third-party voting and the SNP under Gordon Wilson in Dundee during the 1970s and 1980s. CBH 333 (2019) 357-82.

687 TOLOUDIS N, How Local 192 fought for academic freedom and civil rights in Philadelphia, 19341941. JUH 455 (2019) 941-60.

688 TOMCZAK R, Corvée labor and the politics of popular insurrection in Trois-Rivières, 1760-76. JCCH 201 (2019) 1-24.

689 WALKER G \& GREER J, Religion, labour, and national questions: the general election of 1924 in Belfast and Lanarkshire. LHR 843 (2019) 217-239.

690 YOUNG L, The Infant Hercules and the socialist missionary: Ellen Wilkinson in Middlesbrough East, 1924-1931. LHR 841 (2019) 21-45.

\section{Shaping the urban environment Town planning (and environmental control)}

691 AIRGOOD-OBRYCKI W, Suburban status and neighbourhood change. US 5614 (2019) 2935-52.

692 ALLEN J R L, St Michael's, Tilehurst: geological developments since the Enlightenment in a rural-to-urban graveyard in central Berkshire. LandH 402 (2019) 127-42.

693 ALMEROTH-WILLIAMS T, City of beasts: how animals shaped Georgian London. Manchester: Manchester University Press 2019. pp 328.

694 ANDRETTA E \& ROMANO A, Roman urban epistemologies: global space and universal time in the rebuilding of a sixteenth-century city. In DE MUNCK B \& ROMANO A eds, Knowledge and the early modern city: a history of entanglements. Abingdon: Routledge 2019. 194-220.

695 AYKAÇ P, Musealization as an urban process: the transformation of the Sultanahmet district in Istanbul's Historic Peninsula. JUH 456 (2019) 1246-72.

696 BAICS G \& MEISTERLIN L, The grid as algorithm for land use: a reappraisal of the 1811 Manhattan grid. PLP 343 (2019) 391-414.

697 BARLES S \& KNOLL M, Long-term transitions, urban imprint and the construction of hinterlands. In SOENS T, SCHOTT D, TOYKA-SEID M \& DE MUNCK B eds, Urbanizing nature: actors and agency (dis)connecting cities and nature since 1500. Abingdon: Routledge 2019. 29-49.

698 BARRY J, The organization of burial place in post-medieval English cities: Bristol and Exeter c. 15401850. UH 464 (2019) 597-616.

699 BAUMANOVA M, SMEJDA L \& RÜTHER H, Pre-colonial origins of urban spaces in the West African Sahel: street networks, trade, and spatial plurality. JUH 453 (2019) 500-16.

700 BELL M G \& RAMÓN G, Making urban colonial Lima (1535-1650): pipelines and plazas. In ENGEL E A ed, A companion to early modern Lima. Leiden: Brill 2019. 103-26. 
701 BERNHARDT C, Concepts of urban agency and the transformation of urban hinterlands: the case of Berlin, eighteenth to twentieth centuries. In SOENS T, SCHOTT D, TOYKA-SEID M \& DE MUNCK B eds, Urbanizing nature. Abingdon: Routledge 2019. 50-64.

702 BIASILLO R \& ARMIERO M, The transformative potential of a disaster: a contextual analysis of the 1882 flood in Verona, Italy. JHG 661 (2019) 69-80.

703 BOCHARNIKOVA D \& KURG A, Introduction: urban planning and architecture of late socialism. JA 245 (2019) 593-603.

704 BRIMBLECOMBE $\mathrm{P}$, War and urban-industrial air pollution in the UK and the US. In LAAKKONEN S, MCNEILL J R, TUCKER R P \& VUORISALO T eds, The resilient city in World War II: urban environmental histories. London: Palgrave Macmillan 2019. 69-80.

705 BUNING M, Stench and the city: urban odors and technological innovation in early modern Leiden and Batavia. In DE MUNCK B \& ROMANO A eds, Knowledge and the early modern city: a history of entanglements. Abingdon: Routledge 2019. 104-29.

706 CAMPANELLA R, Straight streets in a curvaceous crescent: colonial urban planning and its impact on modern New Orleans. JPH 183 (2019) 196-211.

707 CHAN C S, Belonging to the city: representations of a colonial clock tower in British Hong Kong. JUH 452 (2019) 321-32.

708 CHARRUADAS P \& DELIGNE C, Cities hiding the forests: wood supply, hinterlands and urban agency in the southern Low Countries, thirteenth to eighteenth centuries. In SOENS T, SCHOTT D, TOYKA-SEID M \& DE MUNCK B eds, Urbanizing nature. Abingdon: Routledge 2019. 112-35.

709 COVEY R A \& SILVA M A, Inka urban planning, royal aesthetic signaling, and ruination processes at Huánuco Pampa. IJHA 234 (2019) 893-914.

710 DABOVIĆ T, NEDOVIĆ-BUDIĆ Z \& DJORDJEVIĆ D, Pursuit of integration in the former Yugoslavia's planning. PlP 342 (2019) 215-41.

711 DAVIDS K, Hydraulic experts and the challenges of water in early modern times: European colonial cities compared. In SOENS T, SCHOTT D, TOYKA-SEID M \& DE MUNCK B eds, Urbanizing nature: actors and agency (dis)connecting cities and nature since 1500. Abingdon: Routledge 2019. 180-98.

712 DE LAS RIVAS SANZ, J L \& FERNÁNDEZ-MAROTO M, Planning strategies for a resilient urban fringe in three medium-sized Spanish cities. PlP 344 (2019) 725-35.

713 DERMENTZOGLOU D, DADAKI S, AVGOLOUPIS I \& KATSIFARAKIS K L, Technical study of the historical aqueduct of Kavala, Greece. WH 11 3-4 (2019) 233-52.

714 DESLIPPE D, 'As in a civics text come to life': the East Brooklyn Congregations' Nehemiah Housing Plan and 'citizens power' in the 1980s. JUH 455 (2019) 1030-49.

715 DIERWECHTER Y, The urbanization of green internationalism. London: Palgrave Macmillan 2019. pp xii +175 .

716 DNES M, The rise and fall of London's ringways, 1943-1973. Abingdon: Routledge 2019. pp 142.

717 EDGINGTON D W, Comprehensive planning in Japanese large cities. PLP 341 (2019) 115-32.

718 EMANUEL M, Making a bicycle city: infrastructure and cycling in Copenhagen since 1880. UH 463 (2019) 493-517.

719 ENGELS B, The historical rise and fall of community facility provision standards in the metropolitan planning of Melbourne. PlP 344 (2019) 693-724.

720 FARABAUGH P, Water and steel: the 1977 Johnstown flood and the Bethlehem Steel Corporation. PH 863 (2019) 383-410.

721 FERNANDEZ B, Zoning tools and practices in the Paris' regional plan (1934-1939). HU 552 (2019) $163-82$.

722 FERNÁNDEZ F V, The impact of Arab conquest on the planning of the Iberian cities: Toledo inside walls. In PANZRAM S ed, The power of cities: the Iberian Peninsula from late antiquity to the early modern period. Leiden: Brill 2019. 161-98.

723 FISHER F \& PRESTON R, Light, airy and open: the design and use of the suburban public-house garden in England between the wars. SHGD 391 (2019) 5-21.

724 FLORES M G, The cultural trajectory of the central Peruvian coast, the territory, and its people in the valleys of pre-Hispanic Lima. In ENGEL E A ed, A companion to early modern Lima. Leiden: Brill 2019. 25-45. 
725 FREESTONE R \& JAMES P, Learning from LA: Australian responses to Los Angeles urbanism 19101960. JPH 181 (2019) 44-65.

726 FRIOUX S, Air pollution as urban problem in France, from the mid-nineteenth century to the 1970s. In SOENS T, SCHOTT D, TOYKA-SEID M \& DE MUNCK B eds, Urbanizing nature: actors and agency (dis)connecting cities and nature since 1500. Abingdon: Routledge 2019. 220-42.

727 GALL M, Kirkgate comprehensive development area. BOEC 151 (2019) 81-100.

728 GALVIZ C L, Cities, railways, modernities: London, Paris, and the nineteenth century. Abingdon: Routledge 2019. pp 294.

729 GANAPATHY G \& NARAYANAN N C, Colonial modernity shaping the pipe dream: a historical account of advent of the modern water supply system in Trivandrum. WH 11 3-4 (2019) 107-24.

730 GARRIOCH D, Towards a fire history of European cities (late Middle Ages to late nineteenth century). UH 462 (2019) 202-24.

731 GARRIOCH D, Why didn't Paris burn in the seventeenth and eighteenth centuries? FHS 421 (2019) $35-65$.

732 GELTNER G, Roads to health infrastructure and urban wellbeing in later medieval Italy. Philadelphia: University of Pennsylvania Press 2019. pp 320.

733 GENTILCORE D, 'Cool and tasty waters': managing Naples's water supply, c. 1500 - c. 1750. WH 11 3-4 (2019) 125-51.

734 GERHARDT F C, London 1916: die vergessene Luftschlacht. Leiden: Brill 2019. pp 268.

735 GHOSH R \& KANSAL A, Anthropology of changing paradigms of urban water systems. WH 11 1-2 (2019) 59-73.

736 GORDON C \& LEITH P, Holford: a study of architecture, planning and civic design. Abingdon: Routledge 2019. pp 304.

737 GORDON R \& MALONE P, 'Perpetual power' from the tides in Boston, Massachusetts, USA, 18131858. WH 11 1-2 (2019) 3-29.

738 GOROSTIZA S, Critical networks: urban water supply in Barcelona and Madrid during the Spanish Civil War. In LAAKKONEN S, MCNEILL J R, TUCKER R P \& VUORISALO T eds, The resilient city in World War II: urban environmental histories. London: Palgrave Macmillan 2019. 23-46.

739 GUNN S \& TOWNSEND S C, Automobility and the city in twentieth-century Britain and Japan. London: Bloomsbury Academic 2019. pp 272.

740 HECHT R, Visions of an unrealized park: Chile's Cerro San Cristóbal, 1915-1927. SHGD 393 (2019) 213-33.

741 HOPKINS J \& HEBBERT M, Wythenshawe: Manchester's municipal garden city. In SIES M C, GOURNAY I \& FREESTONE R eds, Iconic planned communities and the challenge of change. Philadelphia: University of Pennsylvania Press 2019. 297-316.

742 INGATE J, Water and urbanism in Roman Britain: hybridity and identity. Abingdon: Routledge 2019. pp 220.

743 JACKSON I, UDUKU O, ADDO I A \& OPONG R A, The Volta River project: planning, housing and resettlement in Ghana, 1950-1965. JA 244 (2019) 512-48.

744 JAKOBSSON E, Stockholm's changing waterscape: a long-term perspective on a city and its flowing water. In SOENS T, SCHOTT D, TOYKA-SEID M \& DE MUNCK B eds, Urbanizing nature: actors and agency (dis)connecting cities and nature since 1500. Abingdon: Routledge 2019. 199-219.

745 JANSSENS E \& SOENS T, Urbanizing water: looking beyond the transition to water modernity in the cities of the southern Low Countries, thirteenth to nineteenth centuries. In SOENS T, SCHOTT D, TOYKA-SEID M \& DE MUNCK B eds, Urbanizing nature. Abingdon: Routledge 2019. 88-111.

746 JOHNSON M W, Mega-events, urban space, and social protest: the Olympia 2000 bid in reunified Berlin, 1990-1993. CEH 524 (2019) 689-712.

747 KARAFANTIS L \& LESLIE S W, 'Suburban warriors': the blue-collar and blue-sky communities of southern California's aerospace industry. JPH 181 (2019) 3-26.

748 KASMI A, The plan as a colonization project: the medina of Tlemcen under French rule, 1842-1920. PLP 341 (2019) 25-42.

749 KEES MAAT D K \& VAN WEE B, The impact of urban proximity, transport accessibility and policy on urban growth: a longitudinal analysis over five decades. EPB 466 (2019) 1000-17.

750 KOLANKIEWICZ V, NICHOLS D \& FREESTONE R, The tribulations of Walter Burley Griffin's final Australian plan: Milleara as 'the garden city of the future' 1925-1965. PlP 345 (2019) 911-23. 
751 KOZLOVSKY R, Pairing Le Corbusier and the affordances of comparisons for architectural history. JA 244 (2019) 549-70.

752 KURG A, Free communication: from Soviet future cities to kitchen conversations. JA 245 2019. 67698.

753 LAAKKONEN S, Environmental history, the Second World War, and urban resilience. In LAAKKONEN S, MCNEILL J R, TUCKER R P \& VUORISALO T eds, The resilient city in World War II: urban environmental histories. London: Palgrave Macmillan 2019. 3-19.

754 LAHTINEN R, Guerrilla gardening? In LAAKKONEN S, MCNEILL J R, TUCKER R P \& VUORISALO $\mathrm{T}$ eds, The resilient city in World War II: urban environmental histories. London: Palgrave Macmillan 2019. 105-26.

755 LAURIAN L, Planning for street trees and human-nature relations: lessons from 600 years of street tree planting in Paris. JPH 184 (2019) 283-310.

756 LEVIN A, South African 'know-how' and Israeli 'facts of life': the planning of Afridar, Ashkelon, 1949-1956. PLP 342 (2019) 285-309.

757 LONGONI R \& WETTER O, Urban stream works in Central Europe 1200-1700: municipal administration, hydraulic engineering and flood reconstruction. WH 1 1-2 (2019) 31-57.

758 LOZANOVSKA M \& MARTEK I, Skopje resurgent: the international confusions of post-earthquake planning, 1963-1967. PLP 343 (2019) 497-513.

759 MAIER J, Mapping Rome's rebirth. In JONES P M, WISCH B \& DITCHFIELD S eds, A companion to early modern Rome, 1492-1692. Leiden: Brill 2019. 285-304.

760 MASER M, Conquered cities: continuity and transformation of urban structures in the Castilian 'Reconquista' territories (11th-14th centuries) - Toledo and Seville. In PANZRAM S ed, The power of cities. Leiden: Brill 2019. 201-46.

761 MASHAYEKHI A, The 1968 Tehran master plan and the politics of planning development in Iran (1945-1979). PlP 345 (2019) 849-76.

762 MASS S, Cost-benefit break down: unplannable spaces in 1970s Glasgow. UH 462 (2019) 309-30.

763 MERRIMAN P, Relational governance, distributed agency and the unfolding of movements, habits and environments: parking practices and regulations in England. EPC 378 (2019) 1400-17.

764 MINNERY J, New Lanark: sustaining Robert Owen's legacy in Scotland. In SIES M C, GOURNAY I \& FREESTONE R eds, Iconic planned communities and the challenge of change. Philadelphia: University of Pennsylvania Press 2019. 21-39.

765 MOATASIM F, Entitled urbanism: elite informality and the reimagining of a planned modern city. US 565 (2019) 1009-25.

766 MURRAY S, The politics and economics of technology: Bankside Power Station and the environment, 1945-81. LJ 442 (2019) 113-32.

767 NIEMI M, A place in its own right: the rural-urban fringe of Helsinki from the early nineteenth century to the present. In SOENS T, SCHOTT D, TOYKA-SEID M \& DE MUNCK B eds Urbanizing nature: actors and agency (dis)connecting cities and nature since 1500. Abingdon: Routledge 2019. 6587.

768 NIEVES A D, Soweto: planning for apartheid and preserving the garden city townships of Johannesburg, South Africa. In SIES M C, GOURNAY I \& FREESTONE R eds, Iconic planned communities and the challenge of change. Philadelphia: University of Pennsylvania Press 2019. 277-96.

769 NYANDORO M, Citizen engagement circumvented: an analysis of liquid waste information/knowledge, control and environmental policy perspectives in Harare, Zimbabwe. EnvH 254 (2019) 575611.

770 OCTAVIANTI T \& CHARLES K, The evolution of Jakarta's flood policy over the past 400 years: the lock-in of infrastructural solutions. EPC 376 (2019) 1102-25.

771 O'REILLY C A, The greening of the city: urban parks and public leisure, 1840-1939. Abingdon: Routledge 2019. pp 154.

772 ORTOLANO G, Thatcher's progress: from social democracy to market liberalism through an English new town. Cambridge: Cambridge University Press 2019. pp xvi +302.

773 PAGE A, Architectures of survival: air war and urbanism in Britain, 1935-52. Manchester: Manchester University Press 2019. pp 256.

774 PAGE A, Fertility from urban wastes? The case for composting in Great Britain, 1920s-1960s. EnvH 251 (2019) 3-22. 
775 PANTE M D, The Esteros and Manila's postwar remaking. In LAAKKONEN S, MCNEILL J R, TUCKER R P \& VUORISALO T eds, The resilient city in World War II: urban environmental histories. London: Palgrave Macmillan 2019. 237-57.

776 PIKÓ L, LESH J \& KOLANKIEWICZ V, Remaking cities: the fourteenth Australasian urban history/ planning history conference, Melbourne, 2018. PLP 341 (2019) 171-9.

777 PLONSKA O \& SARAMIFAR Y, The urban gardens of Havana: seeking revolutionary plants in ideologized spaces. London: Palgrave Macmillan 2019. pp xv +101.

778 PRICE V, Introduction to planning in early American cities. JPH 183 (2019) 169-71.

779 PUGLIANO G, BENASSAI G \& BENASSAI E, Integrating urban and port planning policies in a sustainable perspective: the case study of Naples historic harbour area. PlP 345 (2019) 827-47.

780 PUTRI P W, Sanitizing Jakarta: decolonizing planning and kampung imaginary. PlP 345 (2019) $805-25$.

781 RAGOT G, Cité frugès: Le Corbusier's paradoxical appropriation in Pessac, France. In SIES M C, GOURNAY I \& FREESTONE R eds, Iconic planned communities and the challenge of change. Philadelphia: University of Pennsylvania Press 2019. 238-57.

782 RAJGURU M, The world in the garden: ethnobotany in the contemporary Horniman Museum Garden, London. SHGD 391 (2019) 40-52.

783 REES A \& MELIX B, Landscape discourses and community garden design: creating community gardens in one mid-sized southern US city. SHGD 391 (2019) 90-104.

784 REINBERGER M, Philadelphia versus Baltimore: city planning and aesthetic character in two antebellum American cities. JPH 183 (2019) 212-34.

785 RIEGER D, Twelfth century timber buildings in Lübeck's oldest quarter. In JAHNKE C ed, A companion to medieval Lübeck. Leiden: Brill 2019. 36-65.

786 RIJKE-EPSTEIN T, The politics of filth: sanitation, work, and competing moralities in urban Madagascar 1890s-1977. JAfrH 602 (2019) 229-56.

787 RINNE K W, Renovatio aquae: aqueducts, fountains, and the Tiber River in early modern Rome. In JONES P M, WISCH B \& DITCHFIELD S eds, A companion to early modern Rome, 1492-1692. Leiden: Brill 2019. 324-41.

788 ROBICHAUD A A, Animal city: the domestication of America. Cambridge MA: Harvard University Press 2019. pp 352.

789 ROBSON B \& WYKE T, Surveying the surveyors: Richard Thornton and his publishers. NH 56 1-2 (2019) 97-116.

790 ROHR C, Urban fringes: conquering riversides and lakeshores in the nineteenth century - examples from Austrian and Swiss medium-sized cities. In SOENS T, SCHOTT D, TOYKA-SEID M \& DE MUNCK B eds, Urbanizing nature. Abingdon: Routledge 2019. 243-63.

791 ROSS E \& BIGON L, The urban grid and entangled planning cultures in Senegal. PlP 345 (2019) 779-804.

792 RUIZ-VARONA A, European urban culture, Javier de Mesones-Cabello's planning practice and its legacy in city of Valladolid. PLP 343 (2019) 515-26.

793 RYAN G, Street theater: building monumental avenues in Roman Ephesus and Renaissance Florence. CSSH 611 (2019) 82-110.

794 SCAFETTA N \& MAZZARELLA A, The city of the sun and Pathenope: classical astronomy and the planning of Neapolis, Magna Graecia. JHG 651 (2019) 29-47.

795 SCHLICHTING K M, New York recentered: building the metropolis from the shore. Chicago: University of Chicago Press 2019. pp 328.

796 SCHOTT D, Energizing European cities: from wood provision to solar panels - providing energy for urban demand, 1800-2000. In SOENS T, SCHOTT D, TOYKA-SEID M \& DE MUNCK B eds Urbanizing nature: actors and agency (dis)connecting cities and nature since 1500. Abingdon: Routledge 2019. 136-58.

797 SCHUBERT D, Cities and plans - the past defines the future. PlP 341 (2019) 3-23.

798 SCHUYLER D, Riverside: the first comprehensively designed suburban community in the United States. In SIES M C, GOURNAY I \& FREESTONE R eds, Iconic planned communities and the challenge of change. Philadelphia: University of Pennsylvania Press 2019. 40-60.

799 SHAPIRO-SHAPIN C G, Venetian gondolas on the Illinois River: water analysis and the cultivation of progressivism in the river cities, 1865-1910. WH 11 3-4 (2019) 153-84. 
800 SOENS T, SCHOTT D, TOYKA-SEID M \& DE MUNCK B, Introduction: did cities change nature? A long-term perspective. In SOENS T, SCHOTT D, TOYKA-SEID M \& DE MUNCK B eds, Urbanizing nature: actors and agency (dis)connecting cities and nature since 1500. Abingdon: Routledge 2019. 3-26.

801 STANGL P, San Francisco slaughterhouses and American proto-zoning. JPH 184 (2019) 311-28.

802 STÖGER G, Re-use and recycling in western European cities. In SOENS T, SCHOTT D, TOYKA-SEID M \& DE MUNCK B eds, Urbanizing nature: actors and agency (dis)connecting cities and nature since 1500. Abingdon: Routledge 2019. 159-79.

803 SUN YHEIN C \& SONG K, Planning of public housing in modern Tianjin (1928-1945). PlP 343 (2019) 439-62.

804 TAUBENBÖCK H, GERTEN C, RUSCHE K, SIEDENTOP S \& WURM M, Patterns of Eastern European urbanisation in the mirror of Western trends - convergent, unique or hybrid? EPB 467 (2019) $1206-25$.

805 TOMASZEWICZ A \& MAJCZYK J, Town planning and socialist realism: new Academic District in Wroclaw (Poland) - unfinished projects from the 1950s. PlP 344 (2019) 579-600.

806 TOSLAND B, Planning southern Iraq: placing the progressive theories of Max Lock in Um Qasr, Margil, and Basra in the context of Iraqi national development, 1954-1956. PlP 346 (2019) 1023-44.

807 TOYKA-SEID M, The roots of the sustainable city: the visible waters of the city in modern Mainz and Wiesbaden. In SOENS T, SCHOTT D, TOYKA-SEID M \& DE MUNCK B eds, Urbanizing nature: actors and agency (dis)connecting cities and nature since 1500. Abingdon: Routledge 2019. 294-315.

808 VACHER H, From mise en valeur to cooperation - Ponts-et-Chaussées engineers overseas and the rise of planning expertise in the twentieth century. PLP 341 (2019) 91-113.

809 VAN TUSSENBROEK G, The great rebuilding of Amsterdam (1521-1578). UH 463 (2019) 419-42.

810 VUORISALO T \& KOZLOV M V, Where have all the pigeons gone: wildlife in wartime cities. In LAAKKONEN S, MCNEILL J R, TUCKER R P \& VUORISALO T eds, The resilient city in World War II: urban environmental histories. London: Palgrave Macmillan 2019. 177-200.

811 WALSH J J, The great fire of Rome: life and death in the ancient city. Baltimore, MD: Johns Hopkins University Press 2019. pp 192.

812 WARD B M, Suburbs against the region: homeowner environmentalism in 1970s Detroit. JPH 182 (2019) 83-101.

813 WATSON J M, The suburbanity of Frank Lloyd Wright's Broadacre City. JUH 455 (2019) 1006-29.

814 WEBER $\mathrm{H}$, Twentieth-century waterscapes: cities, consumers, and their dumping grounds. In SOENS T, SCHOTT D, TOYKA-SEID M \& DE MUNCK B eds, Urbanizing nature: actors and agency (dis)connecting cities and nature since 1500. Abingdon: Routledge 2019. 264-93.

815 WHITE J, The 'dismemberment of London': Chamberlain, Abercrombie and the London Plans of 1943-44. LJ 443 (2019) 206-26.

816 WHITE R, A case study in early urban design: Toronto, 1966-1978. PlP 346 (2019) 979-98.

817 WRIGHT V, KEARNS A, ABRAM L \& HAZLEY B, Planning for play: seventy years of ineffective public policy? The example of Glasgow, Scotland. PLP 342 (2019) 243-63.

818 WU X \& ZHAO S, Creating a colonial landscape: park construction in the capital of Manchukuo (1932-1945). SHGD 394 (2019) 321-31.

819 YANG F, IGNATIEVA M, LARSSON A, XIU N \& ZHANG S, Historical development and practices of lawns in China. EnvH 251 (2019) 23-54.

820 YGLESIAS C, To build a metaphor: L'Enfant's design for the city of Washington. JPH 183 (2019) 172-95.

821 YOUNGSON A J, The making of classical Edinburgh. Edinburgh: Edinburgh University Press 2019. pp 448.

\section{Utopian planning and experiments}

822 BANERJI S, A theosophical garden city: designing household life in Bombay, circa 1924. PLP 341 (2019) 65-90.

823 KRIEGER A, City on a hill: urban idealism in America from the Puritans to the present. Cambridge MA: Belknap Press 2019. pp 464. 
824 MILLER M, English garden cities: challenges of conservation and change. In SIES M C, GOURNAY I \& FREESTONE R eds, Iconic planned communities and the challenge of change. Philadelphia: University of Pennsylvania Press 2019. 61-87.

825 SORENSEN A \& WATANABE S J, Den-en Chō: the first Japanese 'garden city'. In SIES M C, GOURNAY I \& FREESTONE R eds, Iconic planned communities and the challenge of change. Philadelphia: University of Pennsylvania Press 2019. 156-75.

\section{Urban renewal}

826 ADAMS D \& LARKHAM P, The everyday experiences of reconstruction and regeneration: from vision to reality in Birmingham and Coventry. Abingdon: Routledge 2019. pp 196.

827 BRENNAN M J, The environmental roots of urban renewal in Boston. JUH 451 (2019) 23-43.

828 DAVIS J, Futurescapes of urban regeneration: ten years of design for the unfolding urban legacy of London's Olympic Games, 2008-2018. PlP 345 (2019) 877-901.

829 DEMSHUK A, Rebuilding after the Reich: sacred sites in Frankfurt, Leipzig, and Wrocław, 19451949. In KEOGH T ed, War and the city: the urban context of conflict and mass destruction. Leiden: Brill 2019. 167-93.

830 DEVIENNE E, Urban renewal by the sea: reinventing the beach for the suburban age in postwar Los Angeles. JUH 451 (2019) 99-125.

831 FOUCHER-DUFOIX V, A name without a referent. Toponymic stakes around the ' 4,000 ' housing estate in La Courneuve. HU 563 (2019) 89-108.

832 HOLLAND D, Forging a consistent vision: the people who shaped Manchester's renewal, 1964-2014. PH 862 (2019) 254-86.

833 KERSHAW J, Affective regeneration in Coventry. In BEGLEY J, DONNELLY T, JARVIS D \& SISSONS P eds, Revival of a city: Coventry in a globalising world. London: Palgrave Macmillan 2019. 125-41.

834 KEYVANIAN C, Papal urban planning and renewal: real and ideal, c. 1471-1667. In JONES P M, WISCH B \& DITCHFIELD S eds, A companion to early modern Rome, 1492-1692. Leiden: Brill 2019. 305-23.

835 LI CHUO, Postwar urban redevelopment and the politics of exclusion: the case of San Francisco's Chinatown. JPH 181 (2019) 27-43.

836 MOAK D G, Une ville des jardins: the Consiglio d'Ornato and the urban transformation of Nice (1832-1860). JUH 454 (2019) 786-812.

837 MONIZ G, CORREIA L M \& GONÇALVES A, Fernando Távora Oporto’s urban renewal: a changing moment in urban rehabilitation policy debate. JUH 454 (2019) 765-85.

838 ROMYN M, 'London badlands': the inner city represented, regenerated. LJ 442 (2019) 133-50.

839 SAUMAREZ SMITH O, Boom cities: architect planners and the politics of radical urban renewal in 1960s Britain. Oxford: Oxford University Press 2019. pp 208.

840 SCHUERMAN M L, Newcomers: gentrification and its discontents. Chicago: University of Chicago Press 2019. pp 320.

841 SIEGEL S, 'Dominant decision-making authority': resident leadership in St. Louis, Missouri, model cities planning. JUH 452 (2019) 333-53.

842 SOLOMON M, 'The ghetto is a gold mine': the racialized temporality of betterment. ILWCH 951 (2019) 76-94.

843 THOMAS J M, Socially responsible practice: the battle to reshape the American Institute of Planners. JPH 184 (2019) 258-81.

844 VALE L J, After the projects: public housing redevelopment and the governance of the poorest Americans. Oxford: Oxford University Press 2019. pp 504.

845 VERLAAN T, Producing space: post-war redevelopment as big business, Utrecht and Hannover 1962-1975. PLP 343 (2019) 415-37.

846 WYCZALKOWSKI C K, VAN HOLM E J, ESNARD A-M \& LAI B S, Uneven neighborhood recovery: hurricane damage and neighborhood change in the Houston-Galveston region since 1970. CitC 182 (2019) 689-709. 


\section{Urban culture}

\section{Research methods, aids and materials}

847 DILLANE A, Crossroads of art and design: musically curating and mediating Irish cultural artifacts in Chicago. EI 54 1\&2 (2019) 82-109.

\section{Urban culture and entertainment}

848 ANDERSON C, Accidental tourists: Yanks in Rome, 1944-1945. JTH 111 (2019) 22-45.

849 BAIN A L \& MARCH L, Urban redevelopment, cultural philanthropy and the commodification of artistic authenticity in Toronto. CitC 181 (2019) 173-94.

850 BALLARIN L, ZANCANARO E \& NICOLOSI P, Giovanni Canestrini's catalogue of the marine malacological collection at the Museo di Zoologia, Padua. ANH 461 (2019) 58-62.

851 BARTIE A, FLEMING L, FREEMAN M, HULME T, HUTTON A \& READMAN P, 'History taught in the pageant way': education and historical performance in twentieth-century Britain. HE 483 (2019) 156-79.

852 BRINKMAN P D, Valuable so far as it goes: establishing zoology at Chicago's Field Columbian Museum, 1893-1894. JHC 311 (2019) 93-109.

853 BRYAN D, CONNOLLY S \& NAGLE J, Civic identity and public space: Belfast since 1780. Manchester: Manchester University Press 2019. pp 248.

854 CANEPARI E \& NUSSDORFER L, A civic identity. In JONES P M, WISCH B \& DITCHFIELD S eds, A companion to early modern Rome, 1492-1692. Leiden: Brill 2019. 29-43.

855 DE LOLLANO PRIETO J S \& ORTIZ A S, The ceroplastic collection of the Royal Veterinary School in Madrid: a history waiting to be recovered. JHC 312 (2019) 291-308.

856 DUNN R \& BARFORD M, Scientific instrument collections in the creation of the National Maritime Museum, Greenwich. JHC 313 (2019) 503-17.

857 FINQUE S, The Callao Contract of 1599: actors set the stage for an early modern Lima. In ENGEL E A ed, A companion to early modern Lima. Leiden: Brill 2019. 424-41.

858 FORTUNA V, Moving otherwise: dance, violence, and memory in Buenos Aires. Oxford: Oxford University Press 2019. pp 264.

859 GRIFFITHS J, 'Rivalling the metropolis': cultural conflict between London and the regions c. 19671973. CBH 334 (2019) 524-47.

860 HALE R, Exhibiting the revolution: expositions at the Museum of the Revolution in Leningrad in the 1920s and 1930s. H 104362 (2019) 649-76.

861 HOLLIER J, HOLLIER A \& CIBOIS A, Building the collections of the Musée académique de Genève: the contribution from Odessa of Léonard Revilliod. ANH 462 (2019) 203-19.

862 HULME T, After the shock city: urban culture and the making of modern citizenship. Woodbridge: Boydell \& Brewer 2019. pp 220.

863 HUNT T, Civic and domestic: collecting the home. HR 92255 (2019) 228-42.

864 JONES J, 'Those intimate little places': cinema-going and public emotion in Bolton, 1930-1954. CulsH 164 (2019) 451-66.

865 KAMINSKA B A, Pieter Bruegel the Elder: religious art for the urban community. Leiden: Brill 2019. pp xiv +241.

866 KAUL A, Pedestrian performances: busking, cosmopolitanism, and Ireland. EI 54 1\&2 (2019) 25174.

867 KENNY S, A 'radical project': youth culture, leisure, and politics in 1980s Sheffield. TCBH 304 (2019) 557-84.

868 LEONG-SALOBIR C, Urban food culture: Sydney, Shanghai and Singapore in the twentieth century. London: Palgrave Macmillan 2019. pp vii +256.

869 MACKEY S, The 'Plan de Paris': who made this viol? Emus 474 (2019) 479-97.

870 MCNALLY J, Hip-hop into the video age: New York teenhood, Malcolm McLaren and the British eye. VCB 201 (2019) 40-63.

871 MCTOMINEY A, The 'Leeds Lake District': water supply, rural environment, and the cultural landscape in Victorian and Edwardian Britain. CulSH 165 (2019) 561-79. 
872 MATIJAŠIĆ I, Herodotus in the theatre at Alexandria? On Athenaeus 14.620D. JHelS 1391 (2019) 83-93.

873 MIKSIC J, Temasek, Singapore and modern national identity construction. In WEBSTER A \& WHITE N J eds, Singapore - two hundred years of the Lion City. Abingdon: Routledge 2019. 207-28.

874 MOEN K, New York's animation culture: advertising, art, design and film, 1939-1940. London: Palgrave Macmillan 2019. pp x +222.

875 NOVOTNY T, Julian of Norwich: how did she know what she knew? HE 485 (2019) 557-74.

876 O'LEARY J, St. Patrick meets St. Louis: the display of the Irish at the 1904 St. Louis World's Fair. EI $543 \& 4$ (2019) 142-71.

877 PROKOPOVYCH M, Das Opernnetzwerk: wiener Operntradition und der habsburgische Kulturraum. In MEYER D R, RATHKOLB O, LÁNG A \& LÁNG O eds, Geschichte der Oper in Wien Band 2: von 1869 bis zur Gegenwart. Vienna: Molden Verlag 2019. 132-53.

878 RAEYMAEKERS D, 'A la mode de Bourgoigne?' The 'Burgundian' ceremonial at the court of Albert and Isabella in Brussels (1598-1621). DC 431 (2019) 47-62.

879 RIJKS M, A painter, a collector, and a horseshoe crab: connoisseurs of art and nature in early modern Antwerp. JHC 312 (2019) 343-61.

880 RODRICK A B, Self-help and civic culture: citizenship in Victorian Birmingham. Abingdon: Routledge 2019. pp 272.

881 ROSCHER M \& WÖBSE A-K, Resilience behind bars: animals and zoo experience in wartime London and Berlin. In LAAKKONEN S, MCNEILL J R, TUCKER R P \& VUORISALO T eds, The resilient city in World War II: urban environmental histories. London: Palgrave Macmillan 2019. 151-75.

882 RYAN M A, Magic in medieval Venice. HC 178 (2019) 1-9.

883 SAI S-M, Dressing up subjecthood: Straits Chinese, the queue, and contested citizenship in colonial Singapore. JICH 473 (2019) 446-73.

884 SÁNCHEZ C A G, The book and western culture in 16th-century Lima. In ENGEL E A ed, A companion to early modern Lima. Leiden: Brill 2019. 404-23.

885 SAUMAREZ SMITH O, The lost world of the British leisure centre. HWJ 881 (2019) 180-203.

886 SCHELLENBERG R, The literary legacy of the Düsseldorfer Gemäldegalerie. JHC 311 (2019) 31-40.

887 SCHRAVEN M, Roma theatrum mundi: festivals and processions in the ritual city. In JONES P M, WISCH B \& DITCHFIELD S eds, A companion to early modern Rome, 1492-1692. Leiden: Brill 2019. 247-65.

888 SMITH P, Editorial: city, space, and spectacle in nineteenth-century theatre and performance. NCTF 462 (2019) 113-18.

889 STAGG A, William Cobbett, James Gillray and the market for caricatures in 1790s Philadelphia. PQ 363 (2019) 275-85.

890 STELL M \& POCOCK C, In community hands: memory and the material culture legacy of a mega sporting event: commemorating the 1982 XII Commonwealth Games in Brisbane. IJHS 366 (2019) 551-69.

891 TANGA M, Arte ambientale, urban space, and participatory art. Abingdon: Routledge 2019. pp 206.

892 TULCHIN A A, Weekly enlightenment: the Affiches de Bordeaux, 1758-1765. FHS 422 (2019) 175-202.

893 VAN BRUAENE A-L, The theatrum as an urban site of knowledge in the Low Countries, c. 15601620. In DE MUNCK B \& ROMANO A eds, Knowledge and the early modern city: a history of entanglements. Abingdon: Routledge 2019. 33-58.

894 VERRIET J, Football clubs, city images and cultural differentiation: identifying with rivalling Vitesse Arnhem and NEC Nijmegen. UH 462 (2019) 266-87.

895 WAY J T, City streets in rural places: emerging cities, youth cultures, and the neoliberalization of Guatemala. JSocH 531 (2019) 76-106.

896 WILLIAMS H, Artists and the city: mapping the art worlds of eighteenth-century Paris. UH 461 (2019) 106-31.

897 WILSON R J \& TATO M I, The First World War on the streets: Buenos Aires and New York. HU 55 2 (2019) $107-23$.

898 YAN S-C, 'Kangaroo politics, kangaroo ideas, and kangaroo society': the early years of Melbourne Punch in Colonial Australia. VPR 521 (2019) 80-102. 


\section{Forms of entertainment}

899 CALKINS T, More than sound: record stores in majority black neighborhoods in Chicago, Milwaukee, and Detroit, 1970-2010. CitC 183 (2019) 853-73.

900 JENSON O C, Of ships and spectacles: maritime identity and the politics of authenticity in regency London. NCTF 462 (2019) 136-60.

901 ŁUKSZA A, Beyond the empire: British influence on the Warsaw theatre scene in the nineteenth century. BatW 121 (2019) 89-111.

902 PIÉTU D, The age war? The city's responses to annoyances caused by children's games (Paris, 1880s1930s). HU 541 (2019) 79-100.

903 SHANNON M L, The multiple lives of Billy Waters: dangerous theatricality and networked illustrations in nineteenth-century popular culture. NCTF 462 (2019) 161-89.

904 WEST S, Virtual reality avant le lettre: Loutherbourg and the origins of urban spectacle. NCTF 462 (2019) 119-35.

\section{Exchange of information}

905 BEELEY P, Practical mathematicians and mathematical practice in later seventeenth-century London. BJHS 522 (2019) 225-48.

906 BENNETT J \& HIGGITT R, London 1600-1800: communities of natural knowledge and artificial practice. BJHS 522 (2019) 183-96.

907 DE MUNCK B \& ROMANO A, Knowledge and the early modern city. In DE MUNCK B \& ROMANO A eds, Knowledge and the early modern city: a history of entanglements. Abingdon: Routledge 2019. 1-30.

908 ELGADDARI S, Hanmer Warrington and imperial intelligence-gathering in Tripoli, 1814-36. In SUONPÄÄ M \& WRIGHT O eds, Diplomacy and intelligence in the nineteenth-century Mediterranean world. London: Bloomsbury Academic 2019. 37-56.

909 HIGGITT R, 'Greenwich near London': the Royal Observatory and its London networks in the seventeenth and eighteenth centuries. BJHS 522 (2019) 297-322.

910 KILBURN-TOPPIN J, 'A place of great trust to be supplied by men of skill and integrity': assayers and knowledge cultures in late sixteenth- and seventeenth-century London. BJHS 522 (2019) 197-223.

911 KINZELBACH A \& RUISINGER M M, Trading information: the city of Nuremberg and the birth of a Latin medical weekly. In MENDELSOHN J A, KINZELBACH A \& SCHILLING R eds, Civic medicine: physician, polity, and pen in early modern Europe. Abingdon: Routledge 2019. 284-305.

912 LINCOLN E, Printers and publishers in early modern Rome. In JONES P M, WISCH B \& DITCHFIELD S eds, A companion to early modern Rome, 1492-1692. Leiden: Brill 2019. 546-63.

913 MARGÓCSY D, Technology transfer, ship design and urban policy in the age of Nicolaes Witsen. In DE MUNCK B \& ROMANO A eds, Knowledge and the early modern city: a history of entanglements. Abingdon: Routledge 2019. 154-66.

914 MOXHAM N, Natural Knowledge, Inc.: the Royal Society as a metropolitan corporation. BJHS 522 (2019) 249-71.

915 OLDFIELD P, Urban panegyric and the transformation of the medieval city, 1100-1300. Oxford: Oxford University Press 2019. pp 224.

916 ÖSTLUND J, The Swedish consulate in Tripoli and information-gathering on diplomacy, everyday life and the slave trade, 1795-1844. In SUONPÄÄ M \& WRIGHT O eds, Diplomacy and intelligence in the nineteenth-century Mediterranean world. London: Bloomsbury Academic 2019. 17-36.

917 SIMMONS A, Trade, knowledge and networks: the activities of the Society of Apothecaries and its members in London, c. 1670 - c. 1800. BJHS 522 (2019) 273-96.

918 TOLONEN M, LAHTI L, ROIVAINEN H \& MARJANEN J, A quantitative approach to bookprinting in Sweden and Finland, 1640-1828. HM 521 (2019) 57-78.

919 WINTERBOTTOM A, An experimental community: the East India Company in London, 16001800. BJHS 522 (2019) 323-43. 


\section{Education}

920 ALIX S-A, The hand as agent of the mind? The irony of manual training reform in Menomonie, Wisconsin (1890-1920). HE 484 (2019) 479-95.

921 ANDERSON J, The use of the University of Tartu Art Museum collection in teaching between 1803 and 1918. HE 485 (2019) 575-90.

922 ANDRETTA E \& FAVINO F, Scientific and medical knowledge in early modern Rome. In JONES P M, WISCH B \& DITCHFIELD S eds, A companion to early modern Rome, 1492-1692. Leiden: Brill 2019. 515-29.

923 BELHOSTE B, Paris savant: capital of science in the age of enlightenment. Oxford: Oxford University Press 2019. pp 328.

924 BUBERT M, Creative opposites: the dispute over the use of philosophy at the medieval Paris University. Leiden: Brill 2019. pp $\mathrm{x}+641$.

925 BUFFETT N P, Crossing the line: high school student activism, the New York High School Student Union, and the 1968 Ocean Hill-Brownsville Teachers' Strike. JUH 456 (2019) 1212-36.

926 CARLSMITH C, The three Rs: education in early modern Rome. In JONES P M, WISCH B \& DITCHFIELD S eds, A companion to early modern Rome, 1492-1692. Leiden: Brill 2019. 485-99.

927 CATALDI L A C, André de Avelar and the city of Coimbra: spaces of knowledge and belief during the early modern Iberian Union. In DE MUNCK B \& ROMANO A eds, Knowledge and the early modern city: a history of entanglements. Abingdon: Routledge 2019. 169-93.

928 DIGAETANO A, The longue durée of school governance in Boston. JUH 454 (2019) 711-46.

929 DITTRICH K, Bilingual primary schools, decorative art and psychotechnics: Luxembourgian education at international exhibitions and congresses, 1870s-1930s. HE 483 (2019) 317-35.

930 DITTRICH K, 'The center of the manual training movement in Germany': die Deutsche Lehrerbildungsanstalt für Knabenhandarbeit in Leipzig, 1887-1914. PaedH 555 (2019) 671-93.

931 FRIPP J L, Caricature, pedagogy, and camaraderie at the French Academy in Rome, 1770-1775. ECS 531 (2019) 43-67.

932 GAMSON D A, The importance of being urban: designing the progressive school district, 1890-1940. Chicago: University of Chicago Press 2019. pp 352.

933 GLASER C, Nostalgia for a beating: discipline, generational authority and corporal punishment at a Soweto High School, c. 1960-2000. HE 483 (2019) 395-409.

934 GOUWENS K, Institutions and dynamics of learned exchange. In JONES P M, WISCH B \& DITCHFIELD S eds, A companion to early modern Rome, 1492-1692. Leiden: Brill 2019. 500-14.

935 HOLDEN P, Spaces of autonomy, spaces of hope: the place of the university in post-colonial Singapore. MAsS 532 (2019) 451-82.

936 JOHANSEN M, 'The supposed paradise of pen and ink': self-education and social mobility in the London Public Library (1880-1930). CulSH 161 (2019) 47-65.

937 KENNERK B, Educating sick children: an Irish hospital school in context, 1900-1980. HE 483 (2019) 356-73.

938 LANDAHL J, Aesthetic modernisation and international comparisons: learning about drawing instruction at the Paris Exposition Universelle of 1900. HE 481 (2019) 41-59.

939 LEONG E, Transformative itineraries and communities of knowledge in early modern Europe: the case of Lazare Rivière's The Practice of Physick. In MENDELSOHN J A, KINZELBACH A \& SCHILLING R eds, Civic medicine. Abingdon: Routledge 2019. 258-83.

940 MOLINO P, The library, the city, the empire: de-provincialising Vienna in the early seventeenth century. In DE MUNCK B \& ROMANO A eds, Knowledge and the early modern city: a history of entanglements. Abingdon: Routledge 2019. 221-48.

941 MURPHY H, Artisanal 'histories' in early modern Nuremberg. In DE MUNCK B \& ROMANO A eds, Knowledge and the early modern city: a history of entanglements. Abingdon: Routledge 2019. $59-80$.

942 O'CONNOR A, 'Une véritable question d'État': controversies over ceremonial robes and corporate citizenship at the University of Paris, 1766-1780. FH 333 (2019) 378-98.

943 PÉREZ P M G, Society and education: the University of San Marcos in the 16th century. In ENGEL E A ed, A companion to early modern Lima. Leiden: Brill 2019. 216-34. 
944 RIJKS M, 'Unusual excrescences of nature': collected coral and the study of petrified luxury in early modern Antwerp. DC 432 (2019) 127-56.

945 SOBRI M H M, Utilitarian sensibility and liberal education: the case of London University, 1825-36. HR 92257 (2019) 585-607.

946 SUFRI M \& CHUNG H J, Following the footsteps of specialist physical education teachers in Singapore's primary schools. IJHS 36 4-5 (2019) 449-73.

947 VAN DAMME S, Boatman, druids and Parisii in Lutetia: archaeologising Parisian society in eighteenth-century civic epistemology. In DE MUNCK B \& ROMANO A eds, Knowledge and the early modern city: a history of entanglements. Abingdon: Routledge 2019. 81-101.

948 WANG L \& YANG J, When overseas education meets a changing local context: the role of Tokyo Higher Technical School in the industrial modernisation of China in the early twentieth century. HE 485 (2019) 607-29.

949 WHITEHEAD K, Inventing and commemorating Queen Elizabeth School, Ilorin, in Nigeria (19562016). HE 482 (2019) 254-72.

\section{Emotions and the senses}

950 BAKER A J, The great music city: exploring music, space and identity. London: Palgrave Macmillan 2019. pp xvii +329 .

951 CHAMBERS T, 'Performed conviviality': space, bordering, and silence in the city. MAsS 533 (2019) 776-99.

952 FAIRE L \& MCHUGH D, Twelve shades of grey: encountering urban colour in the street in British provincial towns, c. 1945-1970. UH 462 (2019) 288-308.

953 FILIPPI D V, Roma sonora: an atlas of Roman sounds and musics. In JONES P M, WISCH B \& DITCHFIELD S eds, A companion to early modern Rome, 1492-1692. Leiden: Brill 2019. 266-81.

954 LASKARIS I, Agency and emotion of young female accusers in the Salem witchcraft trials. CulSH 16 4 (2019) 413-29.

955 MANFREDINI J, The tourist's emotions, tourism of the senses. HU 541 (2019) 101-19.

956 MARÍN-LÓPEZ J, The sonic construction of a new capital: urban soundscapes and acoustic communities in 16th-century Lima. In ENGEL E A ed, A companion to early modern Lima. Leiden: Brill 2019. 442-69.

957 NIKOLOTOV A, Volatile conviviality: joking relations in Moscow's marginal marketplace. MAsS 533 (2019) 874-903.

958 PLATTS H, Multisensory living in ancient Rome: power and space in Roman houses. London: Bloomsbury Academic 2019. pp 360.

959 RIDEAU G, Emotions, senses and religious experience. The case of urban processions in France in the 18th century. HU 541 (2019) 37-54.

960 ROUMAGNOU P-B, The scent of the suburbs: bad odours and the outskirts of Paris in the 18th century. HU 541 (2019) 19-36.

961 VALADE P, A mirror of the senses: Paris, capital of the emotion of joy, serving the monarchy (18th century). HU 541 (2019) 55-77.

962 VALADE P, Senses and emotions in town: criteria of urbanity (16th-21st century). HU 541 (2019) 5-18.

\section{Attitudes towards cities}

\section{Attitudes towards cities}

963 AKKERMAN A, Philosophical urbanism: lineages in mind-environment patterns. London: Palgrave Macmillan 2019. pp xv +193.

964 BEALL J A, Learning the 'grammar' of urban operations: the United States Army and urban combat in World War II. In KEOGH T ed, War and the city: the urban context of conflict and mass destruction. Leiden: Brill 2019. 17-43.

965 BLACKER U, Memory, the city and the legacy of World War II in East Central Europe. Abingdon: Routledge 2019. pp 242.

966 BROWN I G, Edinburgh as Athens: new evidence to support a topographical and intellectual idea current in the early nineteenth century. BOEC 151 (2019) 1-12. 
967 BRUNERO D, Stamford Raffles and James Brooke: colonial legacies and (post)colonial tourism? In WEBSTER A \& WHITE N J eds, Singapore - two hundred years of the Lion City. Abingdon: Routledge 2019. 229-48.

968 COLLINS J, Sites and sightseers: Rome through foreign eyes. In JONES P M, WISCH B \& DITCHFIELD S eds, A companion to early modern Rome, 1492-1692. Leiden: Brill 2019. 564-81.

969 COUSIN L, Babylon, city of gods and kings. HU 563 (2019) 11-33.

970 DALY G, 'The sacking of a town is an abomination': siege, sack and violence to civilians in British officers' writings on the Peninsular War - the case of Badajoz. HR 92255 (2019) 160-82.

971 DAVIS N, JVANAGS G \& MAY A J, Returning to the city: World War One, the repatriation of soldiers and the shaping of Melbourne. HA 161 (2019) 130-52.

972 DAVIS S, 'Government forces dare not penetrate': urban Arab Palestine, no-go areas, and the conflicted course of British counter-insurgency during the Great Rebellion, 1936-1939. In KEOGH T ed, War and the city. Leiden: Brill 2019. 105-38.

973 DE ANTUÑANO E, Mexico City as an urban laboratory: Oscar Lewis, the 'culture of poverty' and the transnational history of the slum. JUH 454 (2019) 813-30.

974 FLANAGAN L, Bexhill-on-Sea, 1917-1919: a maple leaf empire? IJRLH 141 (2019) 39-54.

975 FLOYD E C, Privileging the local: prints and the new world in early modern Lima. In ENGEL E A ed, A companion to early modern Lima. Leiden: Brill 2019. 360-84.

976 GATES-COON R, Anglophile households and British travellers in late eighteenth-century Vienna: 'a very numerous and pleasant English colony'. BatW 122 (2019) 130-50.

977 GUYARD N, The holy city: Lyon's fame and religious image in the early modern period. HU 563 (2019) 35-51.

978 HORNCASTLE J, The death of a city: the Yugoslav Peoples Army siege of Vukovar, 1991, refugee crisis, and its aftermath. In KEOGH T ed, War and the city: the urban context of conflict and mass destruction. Leiden: Brill 2019. 85-104.

979 HUMPHRIES M, Cities and the meanings of late antiquity. Leiden: Brill 2019. pp vi +112 .

980 KENT J, Aesthetics and the revolutionary city. London: Palgrave Macmillan 2019. pp xi +226.

981 LAAKKONEN S, MCNEILL J R, TUCKER R P \& VUORISALO T, Epilogue: what makes a city resilient? In LAAKKONEN S, MCNEILL J R, TUCKER R P \& VUORISALO T eds, The resilient city in World War II: urban environmental histories. London: Palgrave Macmillan 2019. 281-302.

982 LAGRANGE J, Aix-les-Bains, the creation of spa towns and advertising. HU 563 (2019) 129-52.

983 MARCHAL S, Béziers in Languedoc, or, the paths to obscurity. HU 563 (2019) 53-69.

984 PAIVA D \& DE OLIVEIRA F R, The organic metaphor in twentieth-century Lusophone urban geography: cities and their history in the work of Aroldo de Azevedo and Orlando Ribeiro. JHG 631 (2019) 73-81.

985 PARKER L, Panic in London? Attitudes of civilians to air attacks in 1917/18 and 1944/45. In KEOGH $\mathrm{T}$ ed, War and the city: the urban context of conflict and mass destruction. Leiden: Brill 2019. 67-84.

986 PIKÓ L, Milton Keynes in British culture: imagining England. Abingdon: Routledge 2019. pp 218.

987 QUERENGÄSSER A, Saxon cities in the great northern war (1700-1717). In KEOGH T ed, War and the city: the urban context of conflict and mass destruction. Leiden: Brill 2019. 45-66.

988 RABISSI F, The body of Milan in Gabriele Basilico and Michaelangelo Antonioni. JA 248 (2019) 1084-95.

989 RODGER R, Queen Victoria, Edinburgh, and a sense of place. BOEC 151 (2019) 29-44.

990 TELLIER T, The fame of cities, or, how a city conveys its image. Historical stakes and perspectives. HU 563 (2019) 5-10.

991 TELLIER T, Story of an urban metamorphosis: the transformation of the Lille region's image in the era of the post-industrial city (1974-2004). HU 563 (2019) 109-28.

992 THEULÉ F, A comic book as an apple of discord in a new town's identity: Saint-Quentin-en-Yvelines, 1975. HU 563 (2019) 71-87.

993 WEGNER B, Das deutsche Paris: der blick der besatzer 1940-1944. Leiden: Brill 2019. pp 259.

\section{Views of the city in literature, graphics and drama}

994 AHONEN K, LAAKKONEN S \& TSUTSUI W M, Apocalyptic urban future: atomic cities and cinema. In LAAKKONEN S, MCNEILL J R, TUCKER R P \& VUORISALO T eds, The resilient city in World War II: urban environmental histories. London: Palgrave Macmillan 2019. 259-78. 
995 AMEEL L, The 'valley of ashes' and the 'fresh green breast': metaphors from The Great Gatsby in planning New York. PlP 345 (2019) 903-10.

996 BAUER T, Paris in the 1920s: Hemingway's city of sport. SpiH 393 (2019) 254-69.

997 CALLE I B, 'Reina, limpia y pura [queen of heaven, clean and pure]', Italian painters and marian imagery in 16th-century Lima. In ENGEL E A ed, A companion to early modern Lima. Leiden: Brill 2019. 311-36.

998 CUMING E, At home in the world? The ornamental life of sailors in Victorian Sailortown. VL \& $C$ 473 (2019) 463-85.

999 DENNIS R, 'Would you Adam-and-Eve-it?': geography, materiality, and authenticity in novels of Victorian and Edwardian London. In AMEEL L, FINCH J, LAINE S \& DENNIS R eds, The materiality of literary narratives in urban history. Abingdon: Routledge 2019. 167-86.

1000 DI FURIA A J, Maarten van Heemskerck's Rome: antiquity, memory, and the cult of ruins. Leiden: Brill 2019. pp xxv +523 .

1001 ELLING R C, Urbanizing the Iranian public: text, Tehran and 1922. MES 553 (2019) 301-18.

1002 FINCH J, 'Quite an aristocratic place, although in Whitechapel': hospital topographies and Margaret Harkness's writing of London. In AMEEL L, FINCH J, LAINE S \& DENNIS R eds, The materiality of literary narratives in urban history. Abingdon: Routledge 2019. 98-118.

1003 GIMBAL J, The literary adventure of the skyscraper in France (1893-1930): literary narratives and urban architecture between fiction and reality. In AMEEL L, FINCH J, LAINE S \& DENNIS R eds, The materiality of literary narratives in urban history. Abingdon: Routledge 2019. 187-210.

1004 GLASHEEN L, Bombsites, adventure playgrounds and the reconstruction of London: playing with urban space in Hue and Cry. LJ 441 (2019) 54-74.

1005 GLASHEEN L, 'The Casey Court house builders': 1930s children's comics and the material transformation of East London. In AMEEL L, FINCH J, LAINE S \& DENNIS R eds, The materiality of literary narratives in urban history. Abingdon: Routledge 2019. 120-47.

1006 GONZÁLEZ M A, The city in the image/images of the city: the last tapestry of Valladolid. In PANZRAM S ed, The power of cities: the Iberian Peninsula from late antiquity to the early modern period. Leiden: Brill 2019. 247-86.

1007 HILLER G, GROVES P L \& DILNOT A F, Period 1: London - birth of a new order (1558-1659). In HILLER G, GROVES P L \& DILNOT A F eds, An anthology of London in literature, 1558-1914. London: Palgrave Macmillan 2019. 1-40.

1008 HILLER G. GROVES P L \& DILNOT A F, Period 2: London in the Enlightenment (1660-1780). In HILLER G, GROVES P L \& DILNOT A F eds, An anthology of London in literature, 1558-1914. London: Palgrave Macmillan 2019. 41-90.

1009 HILLER G, GROVES P L \& DILNOT A F, Period 3: London - new riches, new squalor (17811870). In HILLER G, GROVES P L \& DILNOT A F eds, An anthology of London in literature, 1558-1914. London: Palgrave Macmillan 2019. 91-176.

1010 HILLER G, GROVES P L \& DILNOT A F, Period 4: London - capital of empire, 1871-1914. In HILLER G, GROVES P L \& DILNOT A F eds, An anthology of London in literature, 1558-1914. London: Palgrave Macmillan 2019. 177-242.

1011 JANSSEN F, 'On the square': constructing the dangers of depression-era London in Ada Chesterton's social investigations. In AMEEL L, FINCH J, LAINE S \& DENNIS R eds, The materiality of literary narratives in urban history. Abingdon: Routledge 2019. 148-66.

1012 LAINE S, Sensory environments of poverty seen through the writings of Runar Schildt, Toivo Tarvas, and Elvi Sinervo. In AMEEL L, FINCH J, LAINE S \& DENNIS R eds, The materiality of literary narratives in urban history. Abingdon: Routledge 2019. 79-97.

1013 LOVASCIO D, Introduction: visions of Rome in Shakespeare. Sha 154 (2019) 311-15.

1014 MCKEOWN A N, Fortification and its discontents from Shakespeare to Milton: trouble in the walled city. Abingdon: Routledge 2019. pp 170.

1015 MERT C, Global cities and organized crime: the shifting urban landscape of Gotham. JPopC 561 (2019) 153-68.

1016 PARRY-DAVIES E, The sea is not a highway: performing maritime histories in the not-quite-global city. ThJ 712 (2019) 437-53. 
1017 PETTERSSON B, Between the street and the drawing room: slumming in Eliot's early poetry. In AMEEL L, FINCH J, LAINE S \& DENNIS R eds, The materiality of literary narratives in urban history. Abingdon: Routledge 2019. 18-40.

1018 PRADHAN A, '... will never become quiet': the materiality of narrative and memory in Trickster City. In AMEEL L, FINCH J, LAINE S \& DENNIS R eds, The materiality of literary narratives in urban history. Abingdon: Routledge 2019. 256-74.

1019 RASCHE A, Herman Rode: the painter of medieval Lübeck and his art production. In JAHNKE C ed, A companion to medieval Lübeck. Leiden: Brill 2019. 306-51.

1020 RIBOUILLAULT D, The cultural landscape of the villa in early modern Rome. In JONES P M, WISCH B \& DITCHFIELD S eds, A companion to early modern Rome, 1492-1692. Leiden: Brill 2019. 367-86.

1021 RÍOS M G, British piracy and the origins of a colonial imaginary in 16th-century Lima. In ENGEL E A ed, A companion to early modern Lima. Leiden: Brill 2019. 385-403.

1022 SALMELA M, Recycling fictions in the city: Don DeLillo and the materiality of waste. In AMEEL L, FINCH J, LAINE S \& DENNIS R eds, The materiality of literary narratives in urban history. Abingdon: Routledge 2019. 41-60.

1023 SCHWAB C, The transforming city in nineteenth-century literary journalism: Ramón de Mesonero Romanos' 'Madrid scenes' and Charles Dickens' 'Street sketches'. UH 462 (2019) 225-45.

1024 TAUBE A, Embodied experience of London's material structures in Peter Ackroyd's Hawksmoor. In AMEEL L, FINCH J, LAINE S \& DENNIS R eds, The materiality of literary narratives in urban history. Abingdon: Routledge 2019. 61-78.

1025 TAYOB H, The unconfessed architectures of Cape Town. In AMEEL L, FINCH J, LAINE S \& DENNIS R eds, The materiality of literary narratives in urban history. Abingdon: Routledge 2019. 212-33.

1026 THORMOD K, Artistic reconfigurations of Rome: an alternative guide to the Eternal City, 19892014. Leiden: Brill 2019. pp xiv +250.

1027 TOMLIN R, Aldgate in Thomas Heywood's Edward the Fourth. LJ 443 (2019) 163-79.

1028 UFFREDUZZI E, Tarantella dance in early cinema: a pillar of Neapolitan urban architecture. NCTF 462 (2019) 210-23.

1029 WILLIAMSON M, 'Strange flesh': hunger and appetite in Shakespeare's Rome. Sha 154 (2019) $316-25$. 